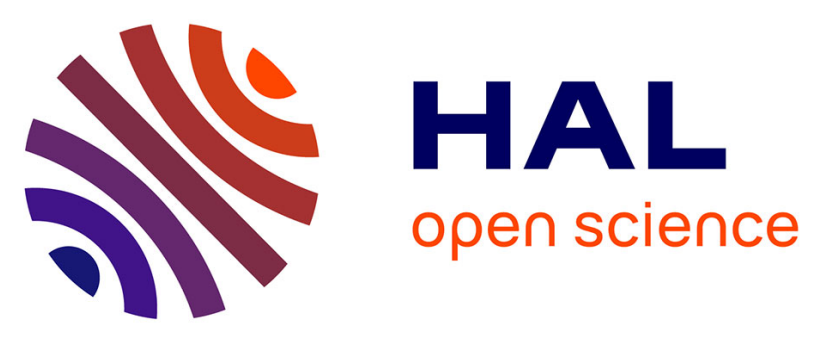

\title{
Synthesis, Structural Characterization and Antiproliferative Activity of Gold(I) and Gold(III) Complexes Bearing Thioether-Functionalized N-Heterocyclic Carbenes
}

Riccardo de Marco, Marco Dal Grande, Marco Baron, Laura Orian, Claudia Graiff, Thierry Achard, Stéphane Bellemin-laponnaz, Alexander Pöthig, Cristina Tubaro

\section{- To cite this version:}

Riccardo de Marco, Marco Dal Grande, Marco Baron, Laura Orian, Claudia Graiff, et al.. Synthesis, Structural Characterization and Antiproliferative Activity of Gold(I) and Gold(III) Complexes Bearing Thioether-Functionalized N-Heterocyclic Carbenes. European Journal of Inorganic Chemistry, 2021, 2021 (40), pp.4196-4206. 10.1002/ejic.202100495 . hal-03401905

\section{HAL Id: hal-03401905 https://hal.science/hal-03401905}

Submitted on 25 Oct 2021

HAL is a multi-disciplinary open access archive for the deposit and dissemination of scientific research documents, whether they are published or not. The documents may come from teaching and research institutions in France or abroad, or from public or private research centers.
L'archive ouverte pluridisciplinaire $\mathbf{H A L}$, est destinée au dépôt et à la diffusion de documents scientifiques de niveau recherche, publiés ou non, émanant des établissements d'enseignement et de recherche français ou étrangers, des laboratoires publics ou privés. 


\title{
Synthesis, Structural Characterization and Antiproliferative
}

\section{Activity of Gold(I) and Gold(III) Complexes Bearing Thioether- Functionalized N-Heterocyclic Carbenes}

\author{
Riccardo De Marco, ${ }^{\dagger[a, b]}$ Marco Dal Grande, ${ }^{\dagger[a]}$ Marco Baron, ${ }^{[a]}$ Laura Orian, ${ }^{[a]}$ Claudia Graiff, ${ }^{[c]}$ Thierry \\ Achard, ${ }^{*[b]}$ Stéphane Bellemin-Laponnaz, ${ }^{*[b]}$ Alexander Pöthig, ${ }^{[d]}$ and Cristina Tubaro* ${ }^{* a]}$
}

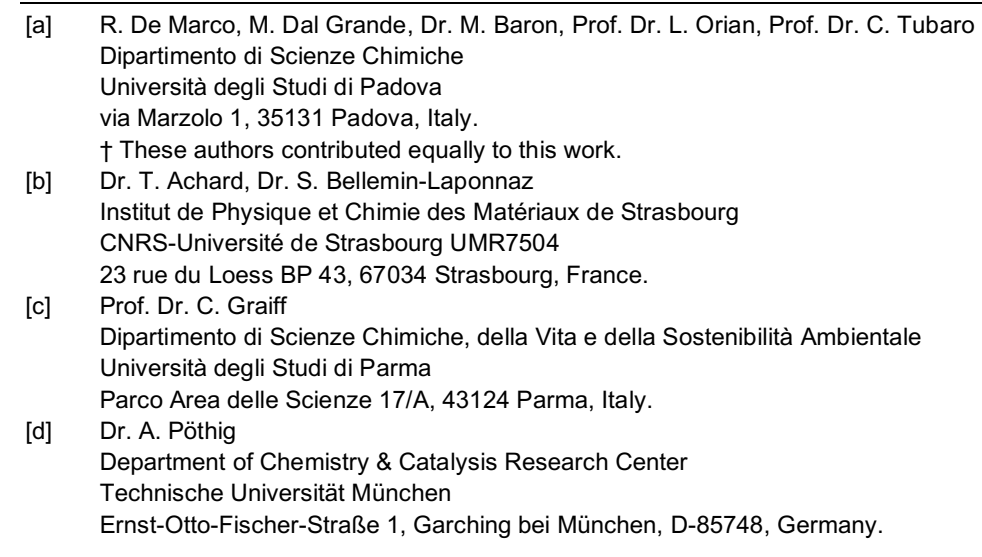

Supporting information for this article is given via a link at the end of the document.

\begin{abstract}
A series of gold(I) and gold(III) complexes with $\mathrm{N}$ heterocyclic carbene ligands functionalized with a pendant thioether group (NHC-SR) was synthesized with straightforward procedures and characterized in solution with NMR spectroscopy and ESI-MS spectrometry, as well as in the solid state by means of single crystal $\mathrm{X}$-ray diffraction analysis. Selected experimental aspects were rationalized through relativistic DFT calculations. The gold(I) and gold(III) complexes displayed moderate in vitro cytotoxicity towards breast cancer cells MCF7.
\end{abstract}

\section{Introduction}

Late transition metal complexes bearing $\mathrm{N}$-heterocyclic carbene ligands (NHCs) have found tremendous successful applications in the last few decades, for examples as homogenous catalysts, metallodrugs or luminescent materials. The success of this class of ligands can be attributed to their strong donating abilities, which confers to the corresponding metal complexes a very high stability, straightforward synthetic procedures and the possibility to tune their steric and electronic properties by changing the nitrogen or backbone substituents. ${ }^{[1-4]}$ Additionally, it is possible to introduce a second donor group (usually $\mathrm{P}, \mathrm{O}$ or $\mathrm{N}$ ) ${ }^{[-10]}$ in the pendant nitrogen substituent, thus giving possibly bidentate ligands. ${ }^{[11]}$ In this regard, $\mathrm{N}$-heterocyclic carbenes bearing a thioether pendant function (Chart 1) are also an interesting class of ligands, that has found application both in homogeneous catalysis and bioinorganic chemistry. Particularly, these Sfunctionalized NHCs may show a chelating ability which results in the formation of highly stable complexes with a strong $\sigma$-donor function (the NHC moieties) and a weaker one (the sulfur atom) $\cdot{ }^{[12-17]}$ The hemilabile equilibrium of sulfur chelating ligand can be of high importance for the development of efficient catalysts: a momentary dissociation of the heteroatom from the metal during a catalytic cycle releases a coordination site and allows the coordination of the substrate, while preserving the stability of the metal complex with the coordination of the NHC ligand. Several studies on the catalytic activity of NHC-SR metal complexes were reported in literature, including aldehyde hydrosilylation, ${ }^{[18]}$ Suzuki-Miyaura cross-coupling reaction ${ }^{[19]}$ and double bond hydrogenation. ${ }^{[20]}$

Another interesting application of thioether-functionalized NHC metal complexes might be in the field of medicinal chemistry as anticancer drugs. ${ }^{[21]}$ Indeed, before reaching the targeting cells, the metal complexes might react with biological sulfur-containing molecules, for instance glutathione (GSH), causing a reduction in the activity towards cancer cells and development of undesired side effects. ${ }^{[22]}$ Thus, co-administration of a "chemoprotective agent", such as S-containing oligopeptides, can significantly reduce the outbreak of side effects. ${ }^{[23]}$ Recently, studies on chemoprotective action and cytotoxic properties of sulfur-containing NHC ruthenium(II) and platinum(II) complexes have been reported by some of us. ${ }^{[24,25]}$ We decided to expand the scope of the metal complexes with such type of ligands and in this paper, we report on the synthesis, characterization and the preliminary antiproliferative results of gold(I) and gold(III) complexes bearing thioether-functionalized NHCs.<smiles>[X][R]SCC[n+]1ccn(CCS[R]SC[Y]=C[Y])c1</smiles>

Chart 1. Examples of imidazolium salts bearing thioether functions. 


\section{Results and Discussion}

The imidazolium salts used in this study are depicted in Chart 2 and their synthesis and characterization were recently reported by some of us. ${ }^{[24,25]}$<smiles>[X]C(=O)SCC[n+]1ccn([R])c1</smiles>

a, $\mathrm{R}=\mathrm{Bn}, \mathrm{R} 1=\mathrm{Ph}, \mathrm{X}=\mathrm{Cl}$

b, $\mathrm{R}=\mathrm{Bn}, \mathrm{R} 1=\mathrm{p}-\mathrm{C}_{6} \mathrm{H}_{4}-\mathrm{OMe}, \mathrm{X}=\mathrm{Br}$

c, $\mathrm{R}=\mathrm{Bn}, \mathrm{R} 1=\mathrm{p}-\mathrm{C}_{6} \mathrm{H}_{4}-\mathrm{Br}, \mathrm{X}=\mathrm{Br}$

d, $R=B n, R 1=E t, X=B r$

e, $R=B n, R 1=C y, X=B r$

f, $R=M e, R 1=p-C_{6} H_{4}-B r, X=B r$

Chart 2. Molecular structure of NHC-SR azolium salts used in this work.

\section{Synthesis of the gold(I) complexes}

The gold(I) complexes can be isolated through two different synthetic procedures: i) synthesis of the corresponding silver(I) complex by reaction of the imidazolium salt with $\mathrm{Ag}_{2} \mathrm{O}$, followed by transmetalation of the carbene ligand to the gold(I) centre using $\mathrm{AuCl}\left(\mathrm{SMe}_{2}\right)$ as gold precursor (Scheme $\left.{ }^{1}\right),{ }^{[26]}$ or ii) metalation of the carbene with potassium carbonate and in the presence of the gold(I) precursor (Scheme 2). ${ }^{[27]}$ In both ways, complexes of general formula $\mathrm{AuX}(\mathrm{NHC}-\mathrm{SR})(\mathrm{X}=\mathrm{Cl}$ or $\mathrm{Br})$ can be isolated. Considering that the second procedure requires a single synthetic step and also the purification from the inorganic salts, formed as by-products, is easier, the majority of the synthesis has been performed with the weak base approach (See experimental section for details).

The formation of the silver(I) complexes $\mathbf{1}$ and $\mathbf{2}$ has been confirmed in the ${ }^{1} \mathrm{H}$ NMR spectra by the disappearance of the signal associated to the $\mathrm{C} 2-\mathrm{H}$ hydrogen; furthermore, in the ${ }^{13} \mathrm{C}$ NMR spectra, the signal of the carbene coordinated to the silver centre is clearly identifiable at $\delta 180 \mathrm{ppm}$, in the typical range of carbene carbons bonded to silver centers. ${ }^{[28]}$ Finally, the ESI-MS spectra present a peak at $\mathrm{m} / \mathrm{z} 757.09$ and 854.89 for $\mathbf{1}$ and $\mathbf{2}$, respectively, which can be associated to the bis-carbene species $\left[\mathrm{Ag}(\mathrm{NHC})_{2}\right]^{+}$. This is not surprising, because it is well known that the silver complexes of general formula $\mathrm{AgX}(\mathrm{NHC})$, generally isolated in chlorinated solvents, can be involved in dynamic equilibria in solution, like $2[\mathrm{AgX}(\mathrm{NHC})] \rightleftarrows\left[\mathrm{Ag}(\mathrm{NHC})_{2}\right]\left[\mathrm{AgX} \mathrm{X}_{2}\right]^{[29,30]}$

The gold $(\mathrm{I})$ complex 3 was isolated via the transmetalation procedure, reacting the silver(I) complex 2 with $\mathrm{AuCl}\left(\mathrm{SMe}_{2}\right)$ in 1:1 ratio. The NMR spectra of silver(I) and gold(I) complexes do not present significant differences in the number, pattern and position of signals, with the exception of the carbene carbon chemical shift ( $\delta 182.1 \mathrm{ppm}$ for 2 and $\delta 171.4 \mathrm{ppm}$ for 3 ). The evidence of the successful formation of the gold(I) complex derives mainly from the ESI mass spectra, which present a signal at $m / z$ 942.99, associable to $\left[\mathrm{Au}(\mathrm{NHC})_{2}\right]^{+}$fragment; also in this case, the formation of the cationic species occurs during the mass spectrometry experiment. In fact, the carbene carbon chemical shift most likely suggests for the gold(I) complex a structure of the type $\mathrm{AuX}(\mathrm{NHC}) \quad(\mathrm{X}=$ halide), since in bis(carbene) species like $\left[\mathrm{Au}(\mathrm{NHC})_{2}\right]^{+}$the carbene carbon chemical shift is usually shifted downfield, at around 180-185 ppm. ${ }^{[31]}$ Finally, complex 3 was unambiguously characterized by $X$-ray diffraction analysis (vide infra).

Gold(I) complexes 4-9 were synthesized through concerted metalation deprotonation mechanism starting directly from the imidazolium salts. ${ }^{[32]}$ The reaction proceeds in acetonitrile in presence of a large excess of $\mathrm{K}_{2} \mathrm{CO}_{3}$ as base (10 equivalents), a slight excess of gold precursor $\mathrm{AuCl}\left(\mathrm{SMe}_{2}\right)$ and eventually the addition of $\mathrm{LiBr}$. The successful coordination of the carbene to the gold $(\mathrm{I})$ centre was confirmed by the disappearance in the ${ }^{1} \mathrm{H}$ NMR spectra of the signal around $8.7 \mathrm{ppm}$ assigned to the acidic $\mathrm{C} 2-\mathrm{H}$ of the imidazolium, and also by the presence in the ${ }^{13} \mathrm{C}$ NMR spectra of a signal around $171-175 \mathrm{ppm}$, assigned to the coordinated carbene carbon, in agreement with literature values. ${ }^{[33]}$

Suitable crystals for X-ray structure analysis of complexes $\mathbf{3}$ and 9 have been obtained by slow diffusion of diethyl ether into an acetonitrile solution of the proper complex. The obtained molecular structures are displayed in Figures 1 and 2, together with selected bond distances $(\AA)$ and angles $\left({ }^{\circ}\right)$. Both structures show the expected atom connectivity with the gold(I) centres almost linearly dicoordinated by an NHC donor and a halide trans to each other. Bond distances and angles agree with literature data for similar gold(I) $\mathrm{NHC}$ complexes. ${ }^{[30,34]}$

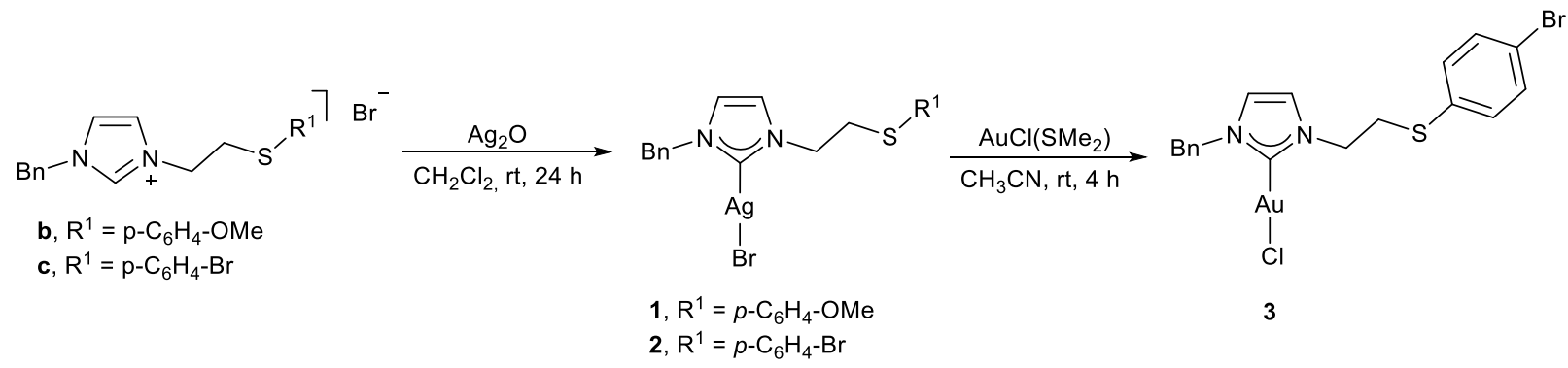

Scheme 1. Synthesis of silver(I) and gold(I) complexes 1-3. 


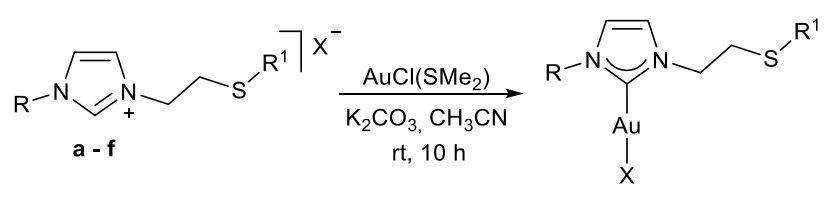

4, $\mathrm{R}=\mathrm{Bn}, \mathrm{R}^{1}=\mathrm{Ph}, \mathrm{X}=\mathrm{Cl}$

5, R = Bn, $\mathrm{R}^{1}=\mathrm{p}-\mathrm{C}_{6} \mathrm{H}_{4}-\mathrm{OMe}, X=\mathrm{Br}$

6, $R=B n, R^{1}=p-C_{6} H_{4}-B r, X=B r$

7, $R=B n, R^{1}=E t, X=B r$

$8, R=B n, R^{1}=C y, X=B r$

9, $R=M e, R^{1}=p-C_{6} H_{4}-B r, X=B r$

Scheme 2. Synthesis of the gold(I) complexes 4-9.

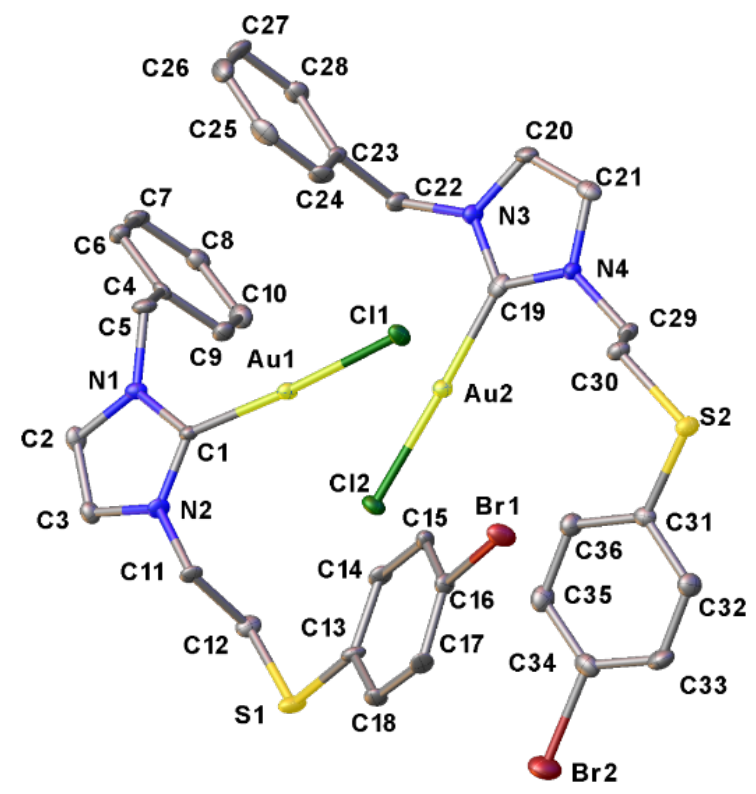

Figure 1. ORTEP view of compound 3, evidencing the dimeric structure build up through interactions explained in the text. Ellipsoids are shown at $50 \%$ probability level. Hydrogen atoms are omitted for clarity. Selected bond distances $(\AA)$ and angles $\left({ }^{\circ}\right)$ : Au1-C1 1.979(4), Au2-C19 1.970(5), Au1-Cl1 2.2948(10), Au2-Cl2 2.2923(10), C1-N1 1.355(5), C1-N2 1.357(5), C19-N3 1.345(5), C19-N4 1.367(5), S1-C12 1.798(4), S1-C13 1.767(4), S2-C30 1.803(4), S2-C31 1.766(4), C16-Br1 1.907(4), C34-Br2 1.904(5), C1-Au1-Cl1 176.59(12), C19-Au2-Cl2 177.33(12), N1-C1-N2 104.3(4), N3-C19-N4 104.1(4), C12-S1-C13 104.1(2), C30-S2-C31 104.4(2).

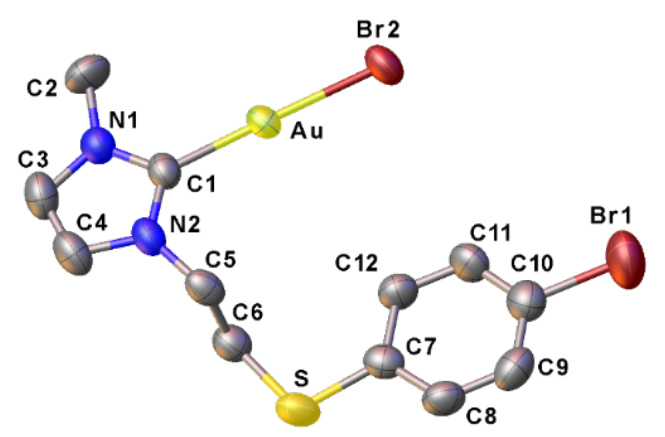

Figure 2. ORTEP view of compound 9. Ellipsoids are shown at $50 \%$ probability level. Hydrogen atoms are omitted for clarity. Selected bond distances $(\AA)$ and angles $\left({ }^{\circ}\right)$ : Au-C1 1.988(6), Au-Br2 2.3966(16), C1-N1
1.351(9), C1-N2 1.334(9), S-C6 1.786(8), S-C7 1.757(8), C10-Br1 1.912(8), C1-Au-Br2 177.72(18), N1-C1-N2 105.5(6), C6-S-C7 105.2(4).

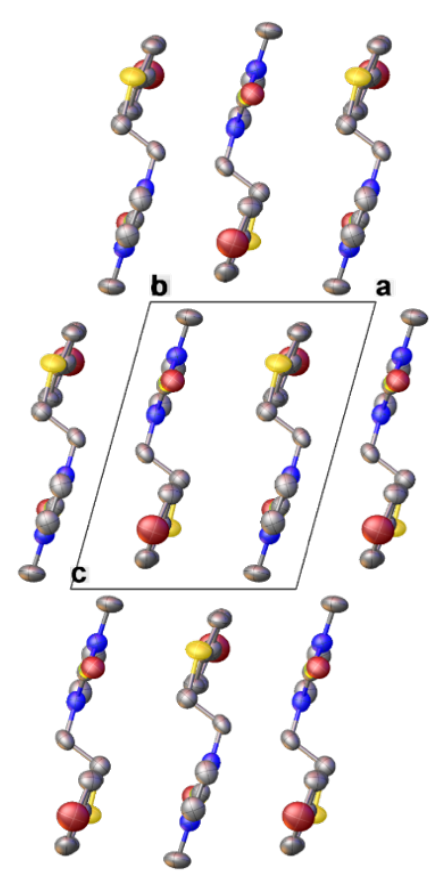

Figure 3. Crystal packing of complex $\mathbf{9}$. View along the $b$ crystallographic axis.

In the molecular structure of complex $\mathbf{3}$, two crystallographic independent complex molecules are found in the asymmetric unit, presenting almost identical structural features in terms of bond distances and angles (Figure 1). The two molecules are coupled together, as a consequence of the presence of three weak attractive intermolecular interactions. There are in fact: (i) a weak aurophilic interaction, with an Au1 $\cdots$ Au2 distance of 3.7371(3) $\AA$; (ii) a $\mathrm{Cl} \cdots \mathrm{H}-\mathrm{C}$ interaction between the chlorine atoms and the methylene thioether protons $(\mathrm{Cl} 1 \cdots \mathrm{H}-\mathrm{C} 30$ and $\mathrm{Cl} 2 \cdots \mathrm{H}-\mathrm{C} 12$ ), and a $\pi-\pi$ stacking interaction between the aromatic rings of the benzyl wingtip substituents of the two molecules (C5-C10 and C23-C28) contributing to the formation of the dimeric aggregate.

In the structure of complex 9 , the two mean planes defined by the $\mathrm{NHC}$ donor $(\mathrm{C} 1, \mathrm{~N} 1, \mathrm{C} 3, \mathrm{C} 4, \mathrm{~N} 2)$ and by the six-membered aromatic ring (C7-C12) are almost parallel with an angle of 2.0(3) ${ }^{\circ}$ between them. The complex thus presents a stretched out or pseudoplanar conformation. The crystal packing of compound $\mathbf{9}$ is shown in Figure 3. Complex molecules arrangement is driven by $\pi-\pi$ interactions running along the crystallographic a axis. No intermolecular aurophilic interaction can be observed.

\section{Synthesis of the gold(III) complexes}

The procedure for the synthesis of gold(III) complexes consists in the oxidative addition of molecular bromine to the corresponding gold $(\mathrm{I})$ complexes ${ }^{[33,35]}$ The reaction is carried out in acetonitrile with 1.2 equivalent of $\mathrm{Br}_{2}$ with respect to the gold(I) complex and the corresponding gold(III) complexes are isolated in excellent yields and without further purification steps (Scheme 3). 
<smiles></smiles><smiles></smiles>

$$
\begin{aligned}
& 10, R^{1}=p-C_{6} H_{4}-O M e \\
& 11, R^{1}=p-C_{6} H_{4}-B r \\
& 12, R^{1}=E t \\
& 13, R^{1}=C y
\end{aligned}
$$

Scheme 3. Synthesis of the gold(III) complexes 10-13.

The ${ }^{1} \mathrm{H}$ NMR spectra of the synthesized gold(III) complexes in deuterated acetonitrile are similar to those observed for the pristine gold(I) complexes, except for a slight downfield shift for all the signals. In contrast, the ${ }^{13} \mathrm{C}$ NMR spectra display a signal for the carbene carbon around $\delta 134-141 \mathrm{ppm}$, in agreement with the values reported in literature, but high-field shifted of ca. $40 \mathrm{ppm}$ compared to the carbene carbon coordinated to a gold(I) centre. ${ }^{[33,35-37]}$ This difference is commonly attributed to an increased Lewis acidity of gold atom, which indicates some withdrawal of $\pi$-electron density from the carbon-carbon double bond to the carbene carbon, through the aromatic system of the heterocyclic ring. ${ }^{[33]}$ Another significant evidence of the successful oxidation came from the ESI-MS spectra, in which the signals related to the gold(III) complexes adducts with $\mathrm{Na}^{+}$or $\mathrm{K}^{+}$are observed.

The behaviour of complex 12 in deuterated chloroform differs from that recorded in deuterated acetonitrile. In particular, in the ${ }^{1} \mathrm{H}$ NMR spectra in deuterated chloroform, the signals of the $\mathrm{CH}_{2}$ protons in $\alpha$ to the sulfur atom are completely absent and also the remaining signals are broad and lacking an evident fine structure (Figure 4a). With the other three gold(III) complexes $\left(10,11\right.$ and 13) this different behaviour in the ${ }^{1} \mathrm{H}$ NMR spectra is not observed when changing the deuterated solvent. Variable temperature ${ }^{1} \mathrm{H}$ NMR spectra were recorded for complex 12 in the range $223-323 \mathrm{~K}$ (Figure $4 \mathrm{~b}$ ) in order to obtain more information on the possible dynamic processes of the complex: at temperatures lower than $273 \mathrm{~K}$ the two signals of the methylene protons in a position to the sulfur atom gradually become visible. The same behaviour is also observed by increasing the temperature up to $323 \mathrm{~K}$. Either increasing or decreasing the temperature, the initial spectrum could be restored, when back to room temperature. This fluxional behaviour suggests that in chloroform a weak coordination of the thioether moiety to the gold centre can occur. ${ }^{[24,38]}$

Finally, it was also possible to obtain few crystals of the complexes 10, 11 and 13, suitable for single crystal XRD analysis by slow evaporation of acetonitrile solution of the proper complex. The molecular structures of the three complexes are reported in Figure 5.

In these molecular structures, the gold atom adopts a square planar geometry as expected for $\mathrm{d}^{8}$ electronic configuration metals, with $\mathrm{C}-\mathrm{Au}-\mathrm{Br}$ trans and $\mathrm{Br}-\mathrm{Au}-\mathrm{Br}_{\text {trans }}$ angles close to linearity. The mean plane defined by the NHC ring (N1-C1-N2C2-C3) is almost perpendicular with respect to the gold(III) mean coordination plane; the angle between the two planes is $76.68(15)^{\circ}$ in $10,83.19(19)^{\circ}$ in $\mathbf{1 1}$ and $73.71(16)$ in 13, in good agreement with the values reported in literature for $\left[\mathrm{AuBr}_{3}(\mathrm{NHC})\right]$ complexes. ${ }^{[33]}$

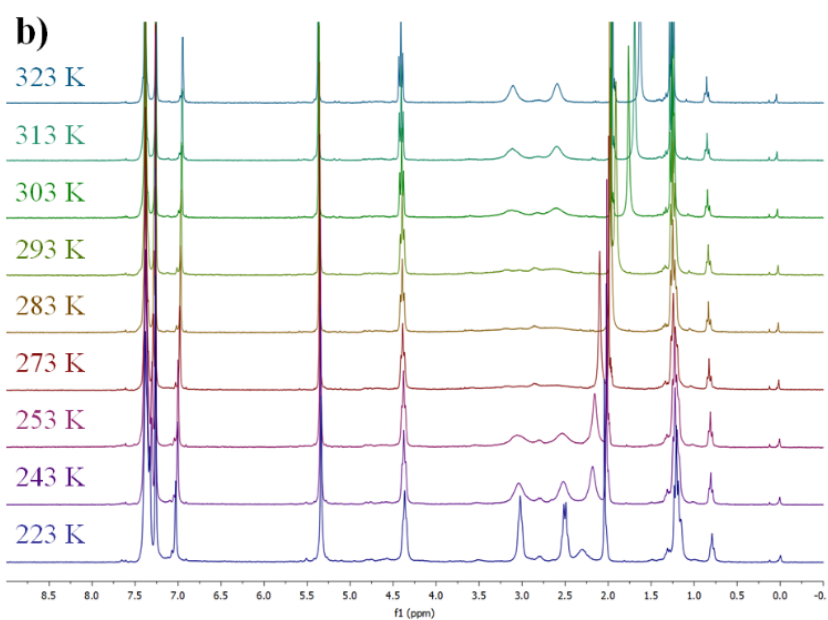

Figure 4. a) ${ }^{1} \mathrm{H}$ NMR spectra of complex 12 in $\mathrm{CD}_{3} \mathrm{CN}$ and $\mathrm{CDCl}_{3}$. b) Variable temperature ${ }^{1} \mathrm{H}$ NMR spectra of complex 12 in $\mathrm{CDCl}_{3}$. 

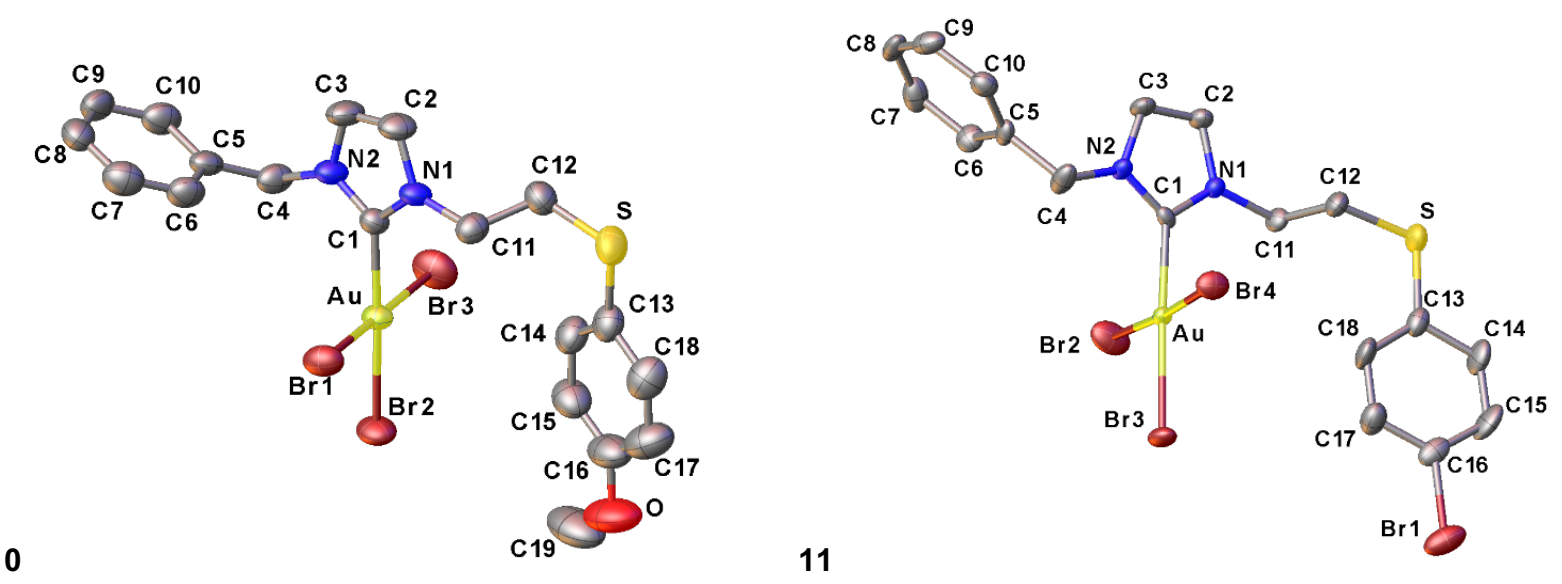

11

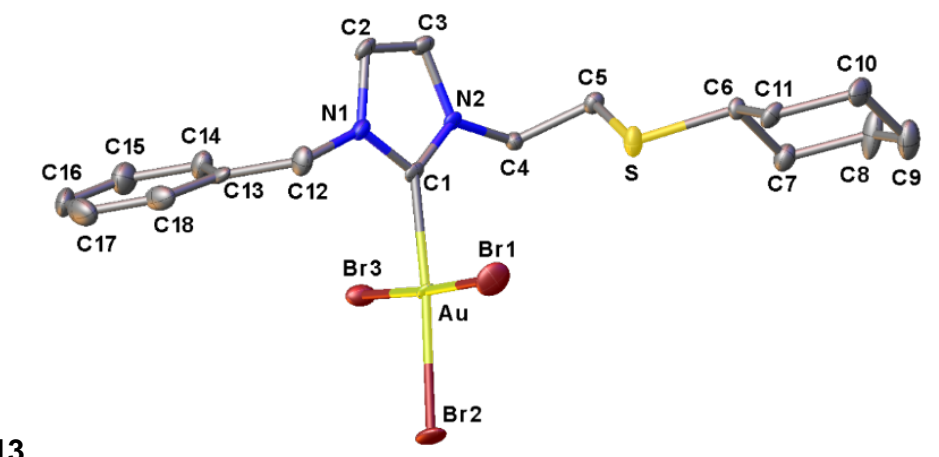

Figure 5. ORTEP view of compounds 10 (top left), 11 (top right) and 13 (bottom). Ellipsoids are shown at 50\% probability level. Hydrogen atoms are omitted for clarity. Selected bond distances $(\AA)$ and angles $\left({ }^{\circ}\right)$ : 10. Au-C1 2.019(4), Au-Br1 2.4185(5), Au-Br2 2.4434(5), Au-Br3 2.4115(6), C1-N1 1.351(5), C1-N2 1.327(5), S-C12 1.800(5), S-C13 1.765(5), O-C16 1.369(7), O-C19 1.433(9), C1-Au-Br1 90.42(12), C1-Au-Br2 176.37(12), C1-Au-Br3 87.32(12), Br3-Au-Br1 176.98(2), N1C1-N2 106.5(4), C12-S-C13 102.6(2), C16-O-C19 118.0(6). 11. Au-C1 2.004(5), Au-Br2 2.4107(7), Au-Br3 2.4471(6), Au-Br4 2.4165(6), C1-N1 1.336(7), C1-N2 1.326(7), S-C12 1.803(6), S-C13 1.773(7), C16-Br1 1.904(6), C1-Au-Br3 177.75(15), Br2-Au-Br4 175.66(2), C1-Au-Br2 88.84(15), C1-Au-Br4 86.93(15), N1-C1N2 107.0(4), C12-S-C13 103.7(3). 13. Au-C1 2.006(6), Au-Br1 2.4287(7), Au-Br2 2.4406(7), Au-Br3 2.4110(7), C1-N1 1.342(7), C1-N2 1.344(7), S-C5 1.815(6), S-C6 1.825(5), C1-Au-Br1 90.25(14), C1-Au-Br2 176.19(14), C1-Au-Br3 86.77(14), Br3-Au-Br1 176.87(2), N1-C1-N2 106.7(5), C5-S-C6 101.3(3).
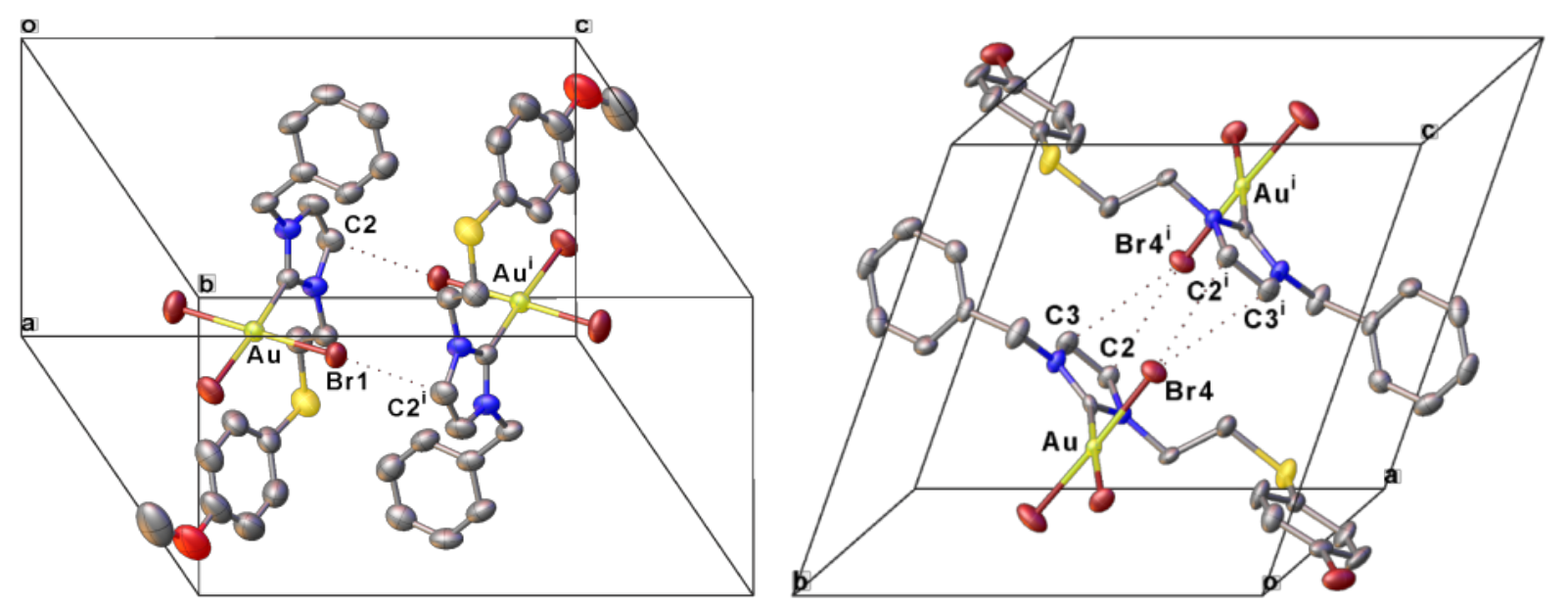

Figure 6. Elemental crystallographic cell of complex 10 (left) and 11 (right), with highlighted $\mathrm{Br} \cdots \mathrm{C}$ short contacts. Symmetry code i = 1-x, 1-y, 1-z. 
In the unit cell of complexes 10 and 11, two molecules of the complex form a dimeric unit, through mutual interactions between a $\mathrm{Br}$ ligand cis with respect to the $\mathrm{NHC}$ donor and the $\mathrm{NHC}$ carbon-carbon double bond of the paired molecule. The $\mathrm{Br} \cdots \mathrm{C}$ distances span from 3.41 to $3.54 \AA$ (Figure 6). In general, the interactions between one coordinated $\mathrm{Br}$ atom and the $\pi$ electron density of the NHC carbon-carbon double bond of another complex molecule are common in the solid state of monocarbene gold(III) complexes. ${ }^{[33,39]}$ This type of interaction is not present in the unit cell of complex 13.

\section{DFT calculations}

The difference observed in the behaviour in chloroform and acetonitrile solution of complexes 10-12 has been further investigated by DFT calculations. In particular, in order to simplify the structure and considering the similarity of complexes 10 and 11, an unsubstituted phenyl ring bonded to the sulphur atom. The structure of complexes $\mathrm{AuBr}_{3}\left({ }^{\mathrm{Bn}} \mathrm{Im} \mathrm{m}^{\mathrm{Et}}\right) 12$ and the simplified complex $\mathrm{AuBr}_{3}\left({ }^{\mathrm{Bn}} / \mathrm{m}^{\mathrm{Ph}}\right)$ have been fully optimised at ZORA-BLYP-D3(BJ)/TZ2P level of theory. The optimised geometry of this last complex is in very good agreement with the crystallographic structures reported for $\mathbf{1 0}$ and $\mathbf{1 1}$ having a parasubstituted phenyl ring.

In addition, we have explored the chelation of the sulfur atom of the $\mathrm{NHC}$ ligand leading to the cationic complex cis-[ $\mathrm{AuBr}_{2}\left(\kappa^{2}-\right.$ $C, S-N H C)]^{+}$. The formation of this species might be in fact responsible for the differences appearing in the NMR spectra. The structures of these cations have been fully optimized at ZORA-BLYP-D3(BJ)/TZ2P level as well. From the single point energies computed in gas phase and in condensed phase, i.e. acetonitrile and chloroform, we estimated the $\Delta E_{\mathrm{r}}$ of the reaction:

$$
\left[\mathrm{AuBr}_{3}\left(\kappa^{1}-\mathrm{C}-\mathrm{NHC}\right)\right] \rightarrow \text { cis- }\left[\mathrm{AuBr}_{2}\left(\kappa^{2}-\mathrm{C}, \mathrm{S}-\mathrm{NHC}\right)\right]^{+}+\mathrm{Br}^{-}
$$

In gas phase, the reaction energy $\Delta \mathrm{E}_{\mathrm{r}}$ is $107.64 \mathrm{kcal} \mathrm{mol}^{-1}$ and $109.77 \mathrm{kcal} \mathrm{mol}^{-1}$ for the ethyl and phenyl substituted compounds, respectively. These values decrease but remain positive when chloroform or acetonitrile are used as solvents (24.69 kcal mol ${ }^{-1}$ and $27.39 \mathrm{kcal} \mathrm{mol}^{-1}$ in chloroform, $4.53 \mathrm{kcal}$ $\mathrm{mol}^{-1}$ and $7.27 \mathrm{kcal} \mathrm{mol}^{-1}$ in acetonitrile, for $\mathbf{1 2}$ and the model compound with the phenyl substituent, respectively). The positive reaction energy agrees with the experimental findings, i.e. all the complexes are isolated as neutral species, without chelation of the sulphur atom. Furthermore, if chelation occurred, the ${ }^{1} \mathrm{H}$ NMR spectrum of the formed complex would be more complicated than the one observed for complex 12, due to the presence of diastereotopic $\mathrm{CH}_{2}$ groups.

These results are also supported by an in depth study on the possible processes converting the species cis-[ $\mathrm{AuBr}_{2}\left(\kappa^{2}-C, S-\right.$ $\mathrm{NHC})]^{+}$into the neutral complex $\left[\mathrm{AuBr}_{3}\left(\kappa^{1}-\mathrm{C}-\mathrm{NHC}\right)\right]$ focusing on two possible pathways: (i) a two-step process involving sulfur dissociation followed by bromide coordination and (ii) concerted mechanism with bromide attacking the gold centre via a square pyramid transition state. The dissociative mechanism can be ruled out because the three-coordinated $\left[\mathrm{AuBr}_{2}\left(\kappa^{1}-\mathrm{C}-\mathrm{NHC}\right)\right]^{+}$is too destabilized. ${ }^{[40]}$

For the concerted pathway, a linear scan of the PES (potential energy surface) was carried out letting $\mathrm{Br}^{-}$approach to the $\mathrm{Au}$ centre along a direction approximately orthogonal to the ring plane. In gas phase, a slightly stabilised reactant complex initially forms (the minimum at Au-S distance 2.4-2.5 $\AA$ in Figure
7), which, through a modest energy barrier for Au-S bond cleavage $\left(4.7\right.$ and $6.4 \mathrm{kcal} \mathrm{mol}^{-1}$, for the complexes $\left[\mathrm{AuBr}_{2}\left(\mathrm{\kappa}^{2}-\right.\right.$ $\mathrm{C}, \mathrm{S}-\mathrm{NHC})]^{+}$with ethyl or phenyl sulphur substituent respectively), is converted into the tribromo complex $\left[\mathrm{AuBr}_{3}\left(\kappa^{1}-\mathrm{C}-\mathrm{NHC}\right)\right]$ (Figure 7). ${ }^{[41]}$

These data represent also an incidental proof that the interaction of the sulphur donor with the gold(III) centre is more favoured when alkyl substituents rather than aryl ones are present.

As a whole, these data suggest that the marked behaviour observed for complex 12 compared to the other synthesised gold(III) complexes cannot be ascribed to a $\mathrm{k}^{2}-\mathrm{C}, \mathrm{S}-\mathrm{NHC}$ ligand coordination, involving dissociation of a bromide anion and formation of a cyclic rigid moiety. Nonetheless, the ligand in the $\left[\mathrm{AuBr}_{3}\left(\kappa^{1}-\mathrm{C}-\mathrm{NHC}\right)\right]$ complex 12 has a remarkable conformational freedom and flexibility, so that the dynamic processes in solution might induce the establishment of a weak interaction between the sulfur atom and the gold(III) centre in the apical position. This interaction with the other complexes $(\mathbf{1 0}, 11$ and 13) is a negligible possibility for the grater steric hindrance of the sulfur substituent. Similar apical weak interactions, although uncommon, are already known for gold(III) complexes with $\mathrm{NHCs}$ having a nitrogen donor function on the side-arm of the heterocyclic carbene ring. ${ }^{[42,43]}$

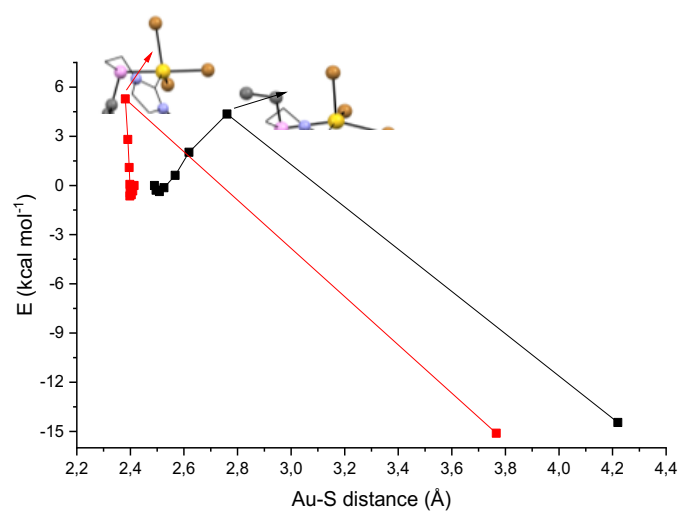

Figure 7. Linear PES scan: energy versus Au-S distance for complex $\left[\operatorname{AuBr}_{2}\left(\kappa^{2}-C, S-N H C\right)\right]^{+}$with ethyl (black) or phenyl (red) sulphur substituent. Level of theory: ZORA-BLYP-D3(BJ)/TZ2P.

\section{Cytotoxic properties of the gold(I) and gold(III) complexes}

Finally, the antiproliferative activity of the synthesized gold(I) and gold(III) was evaluated against the MCF7 cancer cell line (breast cancer), and cisplatin was used as reference for the studies. The half inhibitory concentrations $\left(\mathrm{IC}_{50}\right.$ in $\left.\mu \mathrm{M}\right)$ values induced by these complexes are displayed in Table 1.

All of the tested gold(I/III) complexes show antiproliferative activity, with $\mathrm{IC}_{50}$ values comparable to that measured for the well-known anti-cancer drug cisplatin or for the analogous unfunctionalised $\mathrm{Au}(\mathrm{l})$ complex $\left[\mathrm{AuCl}\left({ }^{\mathrm{Me}} \mathrm{Im} \mathrm{m}^{\mathrm{Me}}\right)\right]$ with the 1,3dimethylimidazol-2-ylidene ligand ${ }^{[44]}$ or other $\mathrm{AuCl}(\mathrm{NHC})$ complexes. ${ }^{[45]}$ Notably, the $\mathrm{IC}_{50}$ values do not vary significantly from gold(I) to gold(III) complexes; this is not surprising considering that it is well known that gold(III) complexes could 
be reduced in biological environment giving the corresponding gold(I) species. ${ }^{[46-48]}$ For this reason, we have studied by in situ NMR the reactivity of the gold(III) complexes 10 (Figure S30 in Supporting Information) and $\mathbf{1 1}$ with reduced glutathione (GSH), a very abundant tripeptide in the cells. We noticed that the gold(III) complexes react quickly with $\mathrm{GSH}$ in a DMSO- $d_{6} / \mathrm{D}_{2} \mathrm{O}$ $(1 / 1)$ mixture in few seconds affording the gold(I) complexes and the glutathione disulphide (GSSG).

Table 1. Half-inhibitory concentrations $I_{50}$ (in $\mu \mathrm{M}$ ) values against MCF7 cancer cells for selected gold(I) and gold(III) complexes $^{[a]}$

\begin{tabular}{|c|c|}
\hline Complex & $\mathrm{IC}_{50}($ in $\mu \mathrm{M})$ \\
\hline $3\left[\mathrm{AuCl}\left({ }^{\mathrm{Bn}} \mathrm{Im}{ }^{\mathrm{PhBr}}\right)\right]$ & $6.06 \pm 0.86$ \\
\hline $5\left[\mathrm{AuBr}\left({ }^{\mathrm{Bn}} \mathrm{Im} \mathrm{m}^{\mathrm{PhOMe}}\right)\right]$ & $7.2 \pm 0.3$ \\
\hline $6\left[\mathrm{AuBr}\left({ }^{\mathrm{Bn}} / \mathrm{m}^{\mathrm{PhBr}}\right)\right]$ & $14.4 \pm 2.9$ \\
\hline $8\left[\operatorname{AuBr}\left({ }^{B n} I m^{C y}\right)\right]$ & $3.98 \pm 0.58$ \\
\hline $9\left[\mathrm{AuBr}\left(\mathrm{Me}^{\mathrm{M}} \mathrm{m}^{\mathrm{PhBr}}\right)\right]$ & $9.12 \pm 0.03$ \\
\hline $10\left[\mathrm{AuBr}_{3}\left({ }^{\mathrm{Bn}} / \mathrm{m}^{\mathrm{PhOMe}}\right)\right]$ & $13.7 \pm 2.6$ \\
\hline $11\left[\mathrm{AuBr}_{3}\left({ }^{\mathrm{Bn}} \mathrm{Im}{ }^{\mathrm{PhBr}}\right)\right]$ & $11.6 \pm 0.9$ \\
\hline cisplatin & $11.9 \pm 0.7$ \\
\hline$\left[\mathrm{AuCl}\left({ }^{\mathrm{Me}} \mid \mathrm{m}^{\mathrm{Me}}\right)\right]^{[\mathrm{b}, \mathrm{c}]}$ & $15 \pm 4$ \\
\hline
\end{tabular}

[a] After 72h of incubation; stock solutions in DMSO for all complexes; stock solutions in $\mathrm{H}_{2} \mathrm{O}$ for cisplatin. [b] ${ }^{\mathrm{Me}} / \mathrm{m}^{\mathrm{Me}}=1$,3-dimethylimidazol-2-ylidene. [c] from ref. 44 .

\section{Conclusion}

A series of gold $(\mathrm{I})$ complexes of general formula [AuX $(\mathrm{NHC})]$ based on thioether-functionalized $\mathrm{NHC}$ ligands have been synthesized by base-assisted metalation and fully characterized, both in solution and in the solid state. The corresponding gold(III) complexes $\left[\mathrm{AuBr}_{3}(\mathrm{NHC})\right]$ were isolated straightforwardly by oxidative addition of bromine to the gold(I) centres. The NHC behaves as a monodentate $\kappa^{1}-\mathrm{C}$ ligand, although with the small ethyl group as substituent on the sulfur atom there are some evidences of a sulfur interaction with the gold centre. The potential chelation of the ligand has been also investigated by means of relativistic DFT calculations.

The complexes displayed moderate antiproliferative activity, without a marked difference between gold(I) and gold(III) species, as expected considering that gold(III) can be reduced by the thiol-functionalized molecules present in the cell.

\section{Experimental Section}

\section{Materials and methods}

Reagents were purchased from Sigma-Aldrich as high-purity products and used as received. All manipulations were carried out using standard Schlenk techniques under an atmosphere of argon. NMR spectra were recorded on a Bruker Avance $300 \mathrm{MHz}$ operating at $300.1 \mathrm{MHz}$ for ${ }^{1} \mathrm{H}$ and $75.5 \mathrm{MHz}$ for ${ }^{13} \mathrm{C}$; chemical shifts $(\delta)$ are reported in units of ppm relative to the residual solvent signals. ESI-MS analyses were performed using a Thermo-Finnigan LCQ-Duo operating in positive ion mode; sample solutions were prepared by dissolving the compounds in acetonitrile and were directly infused into the ESI source by a syringe pump. Elemental analysis were carried out with a Thermo Scientific FLASH 2000 apparatus. The imidazolium salts were prepared following published procedures. ${ }^{[24,25]}$

\section{Synthesis of the silver(I) complexes 1 and 2}

The proper imidazolium salt $(0.25 \mathrm{mmol})$ and $\mathrm{Ag}_{2} \mathrm{O}(0.25 \mathrm{mmol})$ were placed in a two neck round bottom flask. Subsequently, under inert atmosphere, $\mathrm{CH}_{2} \mathrm{Cl}_{2}(10-20 \mathrm{~mL})$ was added and the reaction mixture was left under stirring for 24 hours at room temperature with the exclusion of light. Afterwards, it was filtered with a syringe using a PTFE $0.45 \mu \mathrm{m}$ filter. The volatiles were removed under vacuum and addition of $n$-hexane gave the desired complex as a light grey solid, which was filtered and dried under vacuum.

Complex $\left[\mathrm{AgBr}\left({ }^{\mathrm{Bn}} \mathrm{Im}^{\mathrm{PhOMe}}\right)\right]$ 1. ${ }^{1} \mathrm{H}$ NMR $\left(\mathrm{CD}_{3} \mathrm{CN}\right) \delta 7.50-7.10(\mathrm{~m}, 9 \mathrm{H}, \mathrm{Ar})$, $6.79(\mathrm{~s}, 1 \mathrm{H}, \mathrm{CH}), 6.76(\mathrm{~s}, 1 \mathrm{H}, \mathrm{CH}), 5.22\left(\mathrm{~s}, 2 \mathrm{H}, \mathrm{NCH}_{2} \mathrm{Ph}\right), 4.19(\mathrm{t}, \mathrm{J}=6.6$ $\mathrm{Hz}, 2 \mathrm{H}, \mathrm{NCH}_{2}$ ), 3.71 (s, 3H, CH 3 ), $3.22\left(\mathrm{t}, \mathrm{J}=6.6 \mathrm{~Hz}, 2 \mathrm{H}, \mathrm{CH}_{2} \mathrm{~S}\right) .{ }^{13} \mathrm{C}$ NMR $\left(\mathrm{CD}_{3} \mathrm{CN}\right) \delta 182.1\left(\mathrm{C}_{\mathrm{NCN}}\right), 160.0(\mathrm{Ar}), 137.9(\mathrm{Ar}), 133.8(\mathrm{Ar}), 129.8$ (Ar), 129.1 (Ar), 128.7 (Ar), $125.4(\mathrm{Ar}), 122.8(\mathrm{CH}), 122.7(\mathrm{CH}), 115.8$ (Ar), $56.0\left(\mathrm{CH}_{3}\right), 55.7\left(\mathrm{CH}_{2} \mathrm{Ph}\right), 51.7\left(\mathrm{CH}_{2} \mathrm{~N}\right), 36.9\left(\mathrm{CH}_{2} \mathrm{~S}\right)$. ESI-MS m/z (\%): 757.09 (100) $\left[\mathrm{Ag}\left({ }^{\mathrm{Bn}} / \mathrm{m}^{\mathrm{PhOMe}}\right)_{2}\right]^{+}$.

Complex $\left[\mathrm{AgBr}\left({ }^{\mathrm{Bn}} \mathrm{Im}^{\mathrm{PhBr}}\right)\right]$ 2. ${ }^{1} \mathrm{H}$ NMR $\left(\mathrm{CD}_{3} \mathrm{CN}\right) \delta 7.50-7.10(\mathrm{~m}, 11 \mathrm{H}, \mathrm{Ar})$, $5.18\left(\mathrm{~s}, 2 \mathrm{H}, \mathrm{CH}_{2} \mathrm{Ph}\right), 4.25$ (t, J = $\left.6.5 \mathrm{~Hz}, 2 \mathrm{H}, \mathrm{NCH}_{2}\right), 3.34$ (t, J = $6.5 \mathrm{~Hz}$, $\left.2 \mathrm{H}, \mathrm{CH}_{2} \mathrm{~S}\right) .{ }^{13} \mathrm{C} \mathrm{NMR}\left(\mathrm{CD}_{3} \mathrm{CN}\right) \delta 181.4\left(\mathrm{C}_{\mathrm{NCN}}\right), 137.8(\mathrm{Ar}), 135.2(\mathrm{Ar})$, $133.0(\mathrm{Ar}), 131.4(\mathrm{Ar}), 129.8(\mathrm{Ar}), 129.2(\mathrm{Ar}), 128.6(\mathrm{Ar}), 123.0(\mathrm{CH})$, $122.8(\mathrm{CH}), 120.4(\mathrm{Ar}), 55.7\left(\mathrm{CH}_{2} \mathrm{Ph}\right), 51.5\left(\mathrm{NCH}_{2}\right), 34.7\left(\mathrm{CH}_{2} \mathrm{~S}\right)$. ESI-MS $\mathrm{m} / \mathrm{z}(\%): 854.89(100)\left[\mathrm{Ag}\left({ }^{\mathrm{Bn}} \mathrm{Im}^{\mathrm{PhBr}}\right)_{2}\right]^{+}$.

\section{Synthesis of the gold(I) complex 3 via transmetalation reaction}

$\mathrm{AuCl}\left(\mathrm{SMe}_{2}\right)$ (65 mg, $\left.0.22 \mathrm{mmol}\right)$ was added to a solution of silver(I) complex $2(125 \mathrm{mg}, 0.22 \mathrm{mmol})$ in $\mathrm{CH}_{3} \mathrm{CN}(15 \mathrm{~mL})$. The reaction mixture was left under stirring for 4 hours at room temperature; afterwards, it was filtered with a syringe using a PTFE $0.45 \mu \mathrm{m}$ filter and the solvent was removed under vacuum in order to isolate a white solid. Yield $66 \%$. ${ }^{1} \mathrm{H}$ NMR $\left(\mathrm{CD}_{3} \mathrm{CN}\right) \delta 7.50-7.22(\mathrm{~m}, 9 \mathrm{H}, \mathrm{Ar}), 7.15(\mathrm{~d}, \mathrm{~J}=2.0 \mathrm{~Hz}, 1 \mathrm{H}, \mathrm{CH})$, $7.10(\mathrm{~d}, \mathrm{~J}=2.0 \mathrm{~Hz}, 1 \mathrm{H}, \mathrm{CH}), 5.31$ (s, $\left.2 \mathrm{H}, \mathrm{CH}_{2} \mathrm{Ph}\right), 4.34$ (t, J = $6.8 \mathrm{~Hz}, 2 \mathrm{H}$, $\mathrm{NCH}_{2}$ ), 3.42 (t, J = 6.8 Hz, 2H, CH $\mathrm{CH}_{2} \mathrm{~S} .{ }^{13} \mathrm{C} \mathrm{NMR}\left(\mathrm{CD}_{3} \mathrm{CN}\right) \delta 171.3\left(\mathrm{C}_{\mathrm{NCN}}\right)$, $137.4(\mathrm{Ar}), 135.1(\mathrm{Ar}), 133.0(\mathrm{Ar}), 131.6(\mathrm{Ar}), 129.8(\mathrm{Ar}), 129.2(\mathrm{Ar})$, $128.6(\mathrm{Ar}), 122.8(\mathrm{CH}), 122.2(\mathrm{CH}), 120.4(\mathrm{Ar}), 55.3\left(\mathrm{CH}_{2} \mathrm{Ph}\right), 51.1$ $\left(\mathrm{NCH}_{2}\right), 34.2\left(\mathrm{CH}_{2} \mathrm{~S}\right)$. ESI-MS m/z (\%): $1174.72(20)\left[\mathrm{Au}_{2} \mathrm{Cl}\left({ }^{\mathrm{Bn}} / \mathrm{m}^{\mathrm{PhBr}}\right)_{2}\right]^{+}$, $942.99(100)\left[\mathrm{Au}\left({ }^{\mathrm{Bn}} / \mathrm{m}^{\mathrm{PhBr}}\right)_{2}\right]^{+}$.

Synthesis of the gold(I) complexes via deprotonation of the imidazolium salt: synthesis of complexes 4-9

The proper imidazolium salt (1 equiv.), $\mathrm{AuCl}\left(\mathrm{SMe}_{2}\right)$ (1.05 equiv.) and $\mathrm{K}_{2} \mathrm{CO}_{3}$ (10 equiv.) were placed in a two neck round bottom flask. Subsequently, under inert atmosphere, $\mathrm{CH}_{3} \mathrm{CN}(10-20 \mathrm{~mL})$ was added and the reaction mixture was left under stirring for 10 hours at room temperature with the exclusion of light. Afterwards, it was filtered with a syringe using a PTFE $0.45 \mu \mathrm{m}$ filter. The volatiles were removed under vacuum and addition of $n$-hexane gave the desired complex as a light grey solid, which was filtered and dried under vacuum.

Complex $\left[\mathrm{AuCl}\left({ }^{\mathrm{Bn}} \mathrm{Im}{ }^{\mathrm{Ph}}\right)\right]$ 4. Yield 86\%. ${ }^{1} \mathrm{H}$ NMR $\left(\mathrm{CD}_{3} \mathrm{CN}\right) \delta 7.52-7.00(\mathrm{~m}$, $12 \mathrm{H}, \mathrm{Ar}), 5.30$ (s, 2H, CH $\left.\mathrm{CH}_{2} \mathrm{Ph}\right), 4.31\left(\mathrm{t}, \mathrm{J}=6.9 \mathrm{~Hz}, 2 \mathrm{H}, \mathrm{NCH}_{2}\right), 3.40(\mathrm{t}, \mathrm{J}=$ $\left.6.9 \mathrm{~Hz}, 2 \mathrm{H}, \mathrm{CH}_{2} \mathrm{~S}\right) .{ }^{13} \mathrm{C} \mathrm{NMR}\left(\mathrm{CD}_{3} \mathrm{CN}\right) \delta 171.2\left(\mathrm{C}_{\mathrm{NCN}}\right), 137.3(\mathrm{Ar}), 135.5$ (Ar), $130.2(\mathrm{Ar}), 129.9(\mathrm{Ar}), 129.8(\mathrm{Ar}), 129.2(\mathrm{Ar}), 128.6(\mathrm{Ar}), 127.3(\mathrm{Ar})$, $122.9(\mathrm{CH}), 122.2(\mathrm{CH}), 55.3\left(\mathrm{CH}_{2} \mathrm{Ph}\right), 51.2\left(\mathrm{NCH}_{2}\right), 34.4\left(\mathrm{CH}_{2} \mathrm{~S}\right)$. ESIMS $m / z(\%): 785.17(100)\left[\mathrm{Au}\left({ }^{\mathrm{Bn}} \mathrm{Im} \mathrm{m}^{\mathrm{Ph}}\right)_{2}\right]^{+}$.

Complex $\left[\mathrm{AuBr}\left({ }^{\mathrm{Bn}} \mathrm{Im}{ }^{\mathrm{PhOMe}}\right)\right]$ 5. Yield 95\%. ${ }^{1} \mathrm{H} \mathrm{NMR}\left(\mathrm{CD}_{3} \mathrm{CN}\right) \delta 7.50-7.27$ $(\mathrm{m}, 7 \mathrm{H}, \mathrm{Ar}), 7.15-7.10(\mathrm{~m}, 2 \mathrm{H}, \mathrm{Ar}), 6.90(\mathrm{~m}, 1 \mathrm{H}, \mathrm{CH}), 6.87(\mathrm{~m}, 1 \mathrm{H}, \mathrm{CH})$, $5.33\left(\mathrm{~s}, 2 \mathrm{H}, \mathrm{CH}_{2} \mathrm{Ph}\right), 4.30\left(\mathrm{t}, \mathrm{J}=6.8 \mathrm{~Hz}, 2 \mathrm{H}, \mathrm{NCH}_{2}\right), 3.78\left(\mathrm{~s}, 3 \mathrm{H}, \mathrm{CH}_{3}\right)$, $3.32\left(\mathrm{t}, \mathrm{J}=6.8 \mathrm{~Hz}, 2 \mathrm{H}, \mathrm{CH}_{2} \mathrm{~S}\right) \cdot{ }^{13} \mathrm{C} \mathrm{NMR}\left(\mathrm{CD}_{3} \mathrm{CN}\right) \delta 174.6\left(\mathrm{C}_{\mathrm{NCN}}\right), 160.1$ (Ar), 137.4 (Ar), $134.0(\mathrm{Ar}), 129.8(\mathrm{Ar}), 129.2(\mathrm{Ar}), 128.6(\mathrm{Ar}), 125.3(\mathrm{Ar})$, $122.6(\mathrm{CH}), 122.1(\mathrm{CH}), 115.9(\mathrm{Ar}), 56.0\left(\mathrm{CH}_{3}\right), 55.2\left(\mathrm{CH}_{2} \mathrm{Ph}\right), 51.2$ $\left(\mathrm{NCH}_{2}\right), 36.3\left(\mathrm{CH}_{2} \mathrm{~S}\right)$. ESI-MS m/z (\%): $845.18(100)\left[\mathrm{Au}\left({ }^{\mathrm{Bn}} \mathrm{Im}^{\mathrm{PhOMe}}\right)_{2}\right]^{+}$. Complex $\left[\mathrm{AuBr}\left({ }^{\mathrm{Bn}} \mathrm{Im} \mathrm{m}^{\mathrm{PhB}}\right)\right]$ 6. Yield $72 \%$. ${ }^{1} \mathrm{H}$ NMR $\left(\mathrm{CD}_{3} \mathrm{CN}\right) \delta 7.57-7.22$ $(\mathrm{m}, 9 \mathrm{H}, \mathrm{Ar}), 7.16(\mathrm{~d}, \mathrm{~J}=2.0 \mathrm{~Hz}, 1 \mathrm{H}, \mathrm{CH}), 7.11(\mathrm{~d}, \mathrm{~J}=2.0 \mathrm{~Hz}, 1 \mathrm{H}, \mathrm{CH})$, 
$5.32\left(\mathrm{~s}, 2 \mathrm{H}, \mathrm{CH}_{2} \mathrm{Ph}\right), 4.35\left(\mathrm{t}, \mathrm{J}=6.8 \mathrm{~Hz}, 2 \mathrm{H}, \mathrm{NCH}_{2}\right), 3.42(\mathrm{t}, \mathrm{J}=6.8 \mathrm{~Hz}$, $\left.2 \mathrm{H}, \mathrm{CH}_{2} \mathrm{~S}\right) .{ }^{13} \mathrm{C}$ NMR $\left(\mathrm{CD}_{3} \mathrm{CN}\right) \delta 174.6\left(\mathrm{C}_{\mathrm{NCN}}\right), 137.3(\mathrm{Ar}), 135.1(\mathrm{Ar})$, $133.1(\mathrm{Ar}), 131.6(\mathrm{Ar}), 129.8(\mathrm{Ar}), 129.2(\mathrm{Ar}), 128.6(\mathrm{Ar}), 122.7(\mathrm{CH})$, 122.2(CH), $120.4(\mathrm{Ar}), 55.2\left(\mathrm{CH}_{2} \mathrm{Ph}\right), 50.9\left(\mathrm{NCH}_{2}\right), 34.2\left(\mathrm{CH}_{2} \mathrm{~S}\right)$. ESI-MS $\mathrm{m} / \mathrm{z}(\%): 1174.72(20)\left[\mathrm{Au}_{2} \mathrm{Cl}\left(\mathrm{Bn}^{\mathrm{B}} \mathrm{m}^{\mathrm{PhBr}}\right)_{2}\right]^{+}, 942.99(100)\left[\mathrm{Au}\left({ }^{\mathrm{Bn}} / \mathrm{m}^{\mathrm{PhBr}}\right)_{2}\right]^{+}$. Complex $\left[\mathrm{AuBr}\left({ }^{\mathrm{Bn}} \mathrm{Im} \mathrm{m}^{\mathrm{Et}}\right)\right]$ 7. Yield $72 \%$. ${ }^{1} \mathrm{H}$ NMR $\left(\mathrm{CD}_{3} \mathrm{CN}\right) \delta 7.36(\mathrm{~m}, 5 \mathrm{H}$, Ar), $7.22(\mathrm{~d}, \mathrm{~J}=1.9 \mathrm{~Hz}, 1 \mathrm{H}, \mathrm{CH}), 7.17(\mathrm{~d}, \mathrm{~J}=1.9 \mathrm{~Hz}, 1 \mathrm{H}, \mathrm{CH}), 5.36(\mathrm{~s}$, $\left.2 \mathrm{H}, \mathrm{CH}_{2} \mathrm{Ph}\right), 4.38\left(\mathrm{t}, \mathrm{J}=6.8 \mathrm{~Hz}, 2 \mathrm{H}, \mathrm{NCH}_{2}\right), 3.09\left(\mathrm{br}, 2 \mathrm{H}, \mathrm{CH}_{2} \mathrm{~S}\right), 2.67(\mathrm{br}$, $\left.2 \mathrm{H}, \mathrm{CH}_{2}\right), 1.23\left(\mathrm{t}, \mathrm{J}=7.4 \mathrm{~Hz}, 3 \mathrm{H}, \mathrm{CH}_{3}\right) .{ }^{1} \mathrm{H}$ NMR $\left(\mathrm{CDCl}_{3}\right) \delta 7.31(\mathrm{~m}, 5 \mathrm{H}$, Ar), $7.06(\mathrm{~d}, \mathrm{~J}=1.9 \mathrm{~Hz}, 1 \mathrm{H}, \mathrm{CH}), 6.88(\mathrm{~d}, \mathrm{~J}=1.9 \mathrm{~Hz}, 1 \mathrm{H}, \mathrm{CH}), 5.33(\mathrm{~s}$, $2 \mathrm{H}, \mathrm{CH}_{2} \mathrm{Ph}$ ), $4.31\left(\mathrm{t}, \mathrm{J}=6.8 \mathrm{~Hz}, 2 \mathrm{H}, \mathrm{NCH}_{2}\right), 2.96(\mathrm{t}, \mathrm{J}=6.8 \mathrm{~Hz}, 2 \mathrm{H}$, $\mathrm{CH}_{2} \mathrm{~S}$ ), 2.51 (q, J = $\left.7.4 \mathrm{~Hz}, 2 \mathrm{H}, \mathrm{CH}_{2}\right), 1.21\left(\mathrm{t}, \mathrm{J}=7.4 \mathrm{~Hz}, 3 \mathrm{H}, \mathrm{CH}_{3}\right) .{ }^{13} \mathrm{C}$ NMR $\left(\mathrm{CDCl}_{3}\right) \delta 174.1$ ( $\left.\mathrm{C}_{\mathrm{NCN}}\right), 135.0(\mathrm{Ar}), 129.1(\mathrm{Ar}), 128.7(\mathrm{Ar}), 128.0$ (Ar), $121.8(\mathrm{CH}), 120.3(\mathrm{CH}), 55.1\left(\mathrm{CH}_{2} \mathrm{Ph}\right), 50.8\left(\mathrm{NCH}_{2}\right), 32.5\left(\mathrm{CH}_{2} \mathrm{~S}\right)$, $26.3\left(\mathrm{CH}_{2}\right), 14.8\left(\mathrm{CH}_{3}\right)$. ESI-MS $\mathrm{m} / \mathrm{z}(\%): 689.20(100)\left[\mathrm{Au}\left({ }^{\mathrm{Bn}} / \mathrm{m}^{\mathrm{Et}}\right) 2\right]^{+}$. Complex $\left[\mathrm{AuBr}\left({ }^{\mathrm{Bn}} \mathrm{L} \mathrm{Cy}\right)\right]$ 8. Yield 84\%. ${ }^{1} \mathrm{H}$ NMR $\left(\mathrm{CD}_{3} \mathrm{CN}\right) \delta 7.36(\mathrm{~m}, 5 \mathrm{H}, \mathrm{Ar})$ $7.20(\mathrm{~d}, J=1.9 \mathrm{~Hz}, 1 \mathrm{H}, \mathrm{CH}), 7.17(\mathrm{~d}, J=1.9 \mathrm{~Hz}, 1 \mathrm{H}, \mathrm{CH}), 5.36(\mathrm{~s}, 2 \mathrm{H}$, $\mathrm{CH}_{2} \mathrm{Ph}$ ), $4.32\left(\mathrm{t}, J=6.9 \mathrm{~Hz}, 2 \mathrm{H}, \mathrm{NCH}_{2}\right), 2.98\left(\mathrm{t}, J=6.9 \mathrm{~Hz}, 2 \mathrm{H}, \mathrm{CH}_{2} \mathrm{~S}\right)$, $2.85-2.64(\mathrm{~m}, 1 \mathrm{H}, \mathrm{CH} \mathrm{Cy}), 1.75-1.12\left(\mathrm{~m}, 10 \mathrm{H}, \mathrm{CH}_{2} \mathrm{Cy}\right) .{ }^{13} \mathrm{C} \mathrm{NMR}$ $\left(\mathrm{CD}_{3} \mathrm{CN}\right) \delta 174.7\left(\mathrm{C}_{\mathrm{NCN}}\right), 137.5(\mathrm{Ar}), 129.8(\mathrm{Ar}), 129.2(\mathrm{Ar}), 128.6(\mathrm{Ar})$, $122.7(\mathrm{CH}), 122.1(\mathrm{CH}), 55.2\left(\mathrm{CH}_{2} \mathrm{Ph}\right), 51.7\left(\mathrm{NCH}_{2}\right), 43.5(\mathrm{CHS}), 34.4$ $\left(\mathrm{CH}_{2} \mathrm{Cy}\right), 31.0\left(\mathrm{CH}_{2} \mathrm{~S}\right), 26.7\left(\mathrm{CH}_{2} \mathrm{Cy}\right), 26.4\left(\mathrm{CH}_{2} \mathrm{Cy}\right)$. ESI-MS m/z (\%): $797.28(100)\left[\mathrm{Au}\left({ }^{\mathrm{Bn} I m^{\mathrm{Cy}}}\right)_{2}\right]^{+}$.

Complex $\left[\mathrm{AuBr}\left({ }^{\mathrm{Me}} \mathrm{Im} \mathrm{m}^{\mathrm{PhBr}}\right)\right]$ 9. Yield $75 \% .{ }^{1} \mathrm{H}$ NMR $\left(\mathrm{CD}_{3} \mathrm{CN}\right) \delta 7.50-7.25$ $(2 \mathrm{~m}, 4 \mathrm{H}, \mathrm{Ar}), 7.11(\mathrm{~d}, \mathrm{~J}=1.8 \mathrm{~Hz}, 1 \mathrm{H}, \mathrm{CH}), 7.03(\mathrm{~d}, \mathrm{~J}=1.8 \mathrm{~Hz}, 1 \mathrm{H}, \mathrm{CH})$, $4.31\left(\mathrm{t}, \mathrm{J}=6.9 \mathrm{~Hz}, 2 \mathrm{H}, \mathrm{NCH}_{2} \mathrm{~N}\right), 3.72\left(\mathrm{~s}, 3 \mathrm{H}, \mathrm{CH}_{3}\right), 3.40(\mathrm{t}, \mathrm{J}=6.9 \mathrm{~Hz}, 2 \mathrm{H}$ $\left.\mathrm{CH}_{2} \mathrm{~S}\right) .{ }^{13} \mathrm{C}$ NMR $\left(\mathrm{CD}_{3} \mathrm{CN}\right) \delta 174.7\left(\mathrm{C}_{\mathrm{NCN}}\right), 135.1(\mathrm{Ar}), 133.0(\mathrm{Ar}), 131.8$ (Ar), $123.3(\mathrm{CH}), 122.1(\mathrm{CH}), 120.5(\mathrm{Ar}), 50.9\left(\mathrm{NCH}_{2}\right), 38.5\left(\mathrm{CH}_{3}\right), 34.3$ $\left(\mathrm{CH}_{2} \mathrm{~S}\right)$. ESI-MS m/z (\%): $790.91(100)\left[\mathrm{Au}\left(\mathrm{Me}^{\mathrm{Me}} \mathrm{m}^{\mathrm{PhBr}}\right)_{2}\right]^{+}$.

\section{Synthesis of the gold(III) complexes via oxidative addition of bromine: synthesis of complexes 10-13}

A solution of bromine in acetonitrile was added to a solution of the proper gold(I) complex in acetonitrile (ca. $10 \mathrm{~mL}$ ) using a $\mathrm{Au}: \mathrm{Br}_{2}$ ratio 1:1.5. The reaction mixture was left under stirring for 2 hours at room temperature. Afterwards, the volatiles were removed under vacuum and addition of $n$ hexane gave the desired complex as a yellow solid, which was filtered and dried under vacuum.

Complex $\left[\mathrm{AuBr}_{3}\left({ }^{\mathrm{Bn}} \mid \mathrm{m}^{\mathrm{PhOMe}}\right)\right]$ 10. Yield $91 \%$. ${ }^{1} \mathrm{H}$ NMR $\left(\mathrm{CD}_{3} \mathrm{CN}\right) \delta 7.50-$ $7.25(\mathrm{~m}, 10 \mathrm{H}, \mathrm{Ar}), 6.95-6.90(\mathrm{~m}, 2 \mathrm{H}, \mathrm{CH}), 5.39\left(\mathrm{~s}, 2 \mathrm{H}, \mathrm{CH}_{2} \mathrm{Ph}\right), 4.34(\mathrm{t}, \mathrm{J}$ $\left.=6.7 \mathrm{~Hz}, 2 \mathrm{H}, \mathrm{NCH}_{2}\right), 3.79\left(\mathrm{~s}, 3 \mathrm{H}, \mathrm{CH}_{3}\right), 3.36\left(\mathrm{t}, \mathrm{J}=6.7 \mathrm{~Hz}, 2 \mathrm{H}, \mathrm{CH}_{2} \mathrm{~S}\right)$. ${ }^{13} \mathrm{C}$ NMR $\left(\mathrm{CD}_{3} \mathrm{CN}\right) \delta 160.0(\mathrm{Ar}), 137.6(\mathrm{Ar}), 134.4\left(\mathrm{C}_{\mathrm{NCN}}\right), 134.0(\mathrm{Ar})$, $129.6(\mathrm{Ar}) 129.5(2 \mathrm{Ar}), 125.9(\mathrm{CH}), 125.1(\mathrm{CH}), 124.0(\mathrm{Ar}), 115.7(\mathrm{Ar})$, $55.9\left(\mathrm{CH}_{3}\right), 54.9\left(\mathrm{CH}_{2} \mathrm{Ph}\right), 50.7\left(\mathrm{NCH}_{2}\right), 34.7\left(\mathrm{CH}_{2} \mathrm{~S}\right)$. ESI-MS $\mathrm{m} / \mathrm{z}(\%)$ : 1004.99 (66) $\left[\mathrm{AuBr}_{2}\left(\mathrm{BnIm}^{\mathrm{PhOMe}}\right)_{2}\right]^{+}, 845.25(92)\left[\mathrm{Au}\left(\mathrm{Bn}^{(\mathrm{C}} \mathrm{m}^{\mathrm{PhOMe}}\right)_{2}\right]^{+}, 800.71$ (40) $\left[\mathrm{AuBr}_{3}\left({ }^{\mathrm{Bn}} \mathrm{Im} \mathrm{m}^{\mathrm{PhOMe}}\right)\right] \mathrm{K}^{+}, 784.62$ (100) $\left[\mathrm{AuBr}_{3}\left(\mathrm{Bn}^{\mathrm{Bn}} \mathrm{m}^{\mathrm{PhOMe}}\right)\right] \mathrm{Na}^{+}, 680.80$ (93) $\left[\mathrm{AuBr}_{2}\left({ }^{\mathrm{Bn}} / \mathrm{m}^{\mathrm{PhOMe}}\right)\right]^{+}$

Complex $\left[\mathrm{AuBr}_{3}\left({ }^{\mathrm{Bn}} / \mathrm{m}^{\mathrm{PhBr}}\right)\right]$ 11. Yield $92 \% .{ }^{1} \mathrm{H}$ NMR $\left(\mathrm{CD}_{3} \mathrm{CN}\right) \delta 7.53-7.25$ (m, 11H, Ar), 5.40 (s, 2H, CH $2 \mathrm{Ph}), 4.39\left(\mathrm{t}, \mathrm{J}=7.0 \mathrm{~Hz}, 2 \mathrm{H}, \mathrm{NCH}_{2}\right), 3.48(\mathrm{t}$, $\left.\mathrm{J}=7.0 \mathrm{~Hz}, 2 \mathrm{H}, \mathrm{CH}_{2} \mathrm{~S}\right) \cdot{ }^{13} \mathrm{C} \mathrm{NMR}\left(\mathrm{CDCl}_{3}\right) \delta 141.0$ ( $\left.\mathrm{CNCN}_{\mathrm{NC}}\right), 132.9(\mathrm{Ar})$, $132.5(\mathrm{Ar}), 132.3(\mathrm{Ar}), 131.5(\mathrm{Ar}), 129.9(\mathrm{Ar}), 129.7(\mathrm{Ar}), 129.4(\mathrm{Ar})$, $124.5(\mathrm{CH}), 122.9(\mathrm{CH}), 121.5(\mathrm{Ar}), 55.2\left(\mathrm{CH}_{2} \mathrm{Ph}\right), 50.3\left(\mathrm{NCH}_{2}\right), 33.3$ $\left(\mathrm{CH}_{2} \mathrm{~S}\right)$. ESI-MS $\mathrm{m} / \mathrm{z}(\%): 1102.79(35)\left[\mathrm{AuBr}_{2}\left({ }^{\mathrm{Bn}} \mathrm{Im}^{\mathrm{PhBr}}\right)_{2}\right]^{+}, 848.63(17)$ $\left[\mathrm{AuBr}_{3}\left({ }^{\mathrm{Bn}} \mathrm{m}^{\mathrm{PhBr}}\right)\right] \mathrm{K}^{+}, \quad 832.57 \quad(12) \quad\left[\mathrm{AuBr}_{3}\left({ }^{\mathrm{Bn}} \mathrm{m}^{\mathrm{PhBr}}\right)\right] \mathrm{Na}^{+}, \quad 730.67$ (8) $\left[\mathrm{AuBr}_{2}\left({ }^{\mathrm{Bn}} / \mathrm{m}^{\mathrm{PhBr}}\right)\right]^{+}$.

Complex $\left.\left[\mathrm{AuBr}_{3}{ }^{(\mathrm{Bn}} / \mathrm{m}^{\mathrm{Et}}\right)\right]$ 12. Yield $90 \%{ }^{1} \mathrm{H}$ NMR $\left(\mathrm{CD}_{3} \mathrm{CN}\right) \delta 7.47(\mathrm{~d}, \mathrm{~J}=$ $2.0 \mathrm{~Hz}, 1 \mathrm{H}, \mathrm{CH}), 7.44-7.38(\mathrm{~m}, 5 \mathrm{H}, \mathrm{Ar}), 7.32(\mathrm{~d}, \mathrm{~J}=2.0 \mathrm{~Hz}, 1 \mathrm{H}, \mathrm{CH})$, $5.42\left(\mathrm{~s}, 2 \mathrm{H}, \mathrm{CH}_{2} \mathrm{Ph}\right), 4.41\left(\mathrm{t}, \mathrm{J}=7.0 \mathrm{~Hz}, 2 \mathrm{H}, \mathrm{NCH}_{2}\right), 3.07(\mathrm{t}, \mathrm{J}=7.0 \mathrm{~Hz}$, $2 \mathrm{H}, \mathrm{CH}_{2} \mathrm{~S}$ ), 2.59 (q, J = $7.3 \mathrm{~Hz}, 2 \mathrm{H}, \mathrm{CH}_{2}$ ), 1.24 (t, J = $7.3 \mathrm{~Hz}, 3 \mathrm{H}, \mathrm{CH}_{3}$ ). ${ }^{1} \mathrm{H}$ NMR $\left(\mathrm{CDCl}_{3}\right) \delta$ 7.38-7.26 (m, $6 \mathrm{H}, \mathrm{Ar}$ and $\left.\mathrm{CH}\right), 6.96(\mathrm{~s}, 1 \mathrm{H}, \mathrm{CH}), 5.36$ (s, 2H, $\mathrm{CH}_{2} \mathrm{Ph}$ ), 4.39 (t, J = $\left.7.0 \mathrm{~Hz}, 2 \mathrm{H}, \mathrm{NCH}_{2}\right), 1.25$ (t, J = $7.3 \mathrm{~Hz}, 3 \mathrm{H}$, $\left.\mathrm{CH}_{3}\right)$, the two $\mathrm{CH}_{2} \mathrm{~S}$ are not visible. ${ }^{13} \mathrm{C}$ NMR $\left(\mathrm{CD}_{3} \mathrm{CN}\right) \delta 138.0(\mathrm{Ar})$, $134.9\left(\mathrm{C}_{\mathrm{NCN}}\right), 130.0(\mathrm{Ar}), 129.9(2 \mathrm{Ar}), 126.1(\mathrm{CH}), 125.2(\mathrm{CH}), 55.2$ $\left(\mathrm{CH}_{2} \mathrm{Ph}\right), 51.5\left(\mathrm{NCH}_{2}\right), 31.3\left(\mathrm{CH}_{2} \mathrm{~S}\right), 26.5\left(\mathrm{CH}_{2}\right), 15.3\left(\mathrm{CH}_{3}\right)$. ESI-MS $\begin{array}{llllllll}\left(\mathrm{CH}_{3} \mathrm{CN}\right) & \mathrm{m} / \mathrm{z} & (\%): & 848.90 & (100) & {\left[\mathrm{Au}\left({ }^{(\mathrm{Bn}} / \mathrm{m}^{\mathrm{Et}}\right)_{2}\right]^{+},} & 602.78 & (40)\end{array}$ $\left[\mathrm{Au}\left({ }^{\mathrm{Bn}} \mathrm{Im} \mathrm{m}^{\mathrm{Et}}\right) \mathrm{Br}_{2}\right]^{+}$.

Complex $\left[\mathrm{AuBr}_{3}\left({ }^{\mathrm{Bn}} / \mathrm{m}^{\mathrm{Cy}}\right)\right]$ 13. Yield $85 \%{ }^{1} \mathrm{H}$ NMR $\left(\mathrm{CD}_{3} \mathrm{CN}\right) \delta 7.47(\mathrm{~d}, \mathrm{~J}=$ $2.0 \mathrm{~Hz}, 1 \mathrm{H}, \mathrm{CH}$ ), 7.40 (bs, $5 \mathrm{H}, \mathrm{Ar}$ ), 7.30 (d, J = 2.0 Hz, 1H, CH), $5.42(\mathrm{~s}$, $2 \mathrm{H}, \mathrm{CH}_{2} \mathrm{Ph}$ ), 4.39 (t, J =7.2 Hz, 2H, NCH 2$), 3.06\left(\mathrm{t}, \mathrm{J}=7.2 \mathrm{~Hz}, 2 \mathrm{H}, \mathrm{CH}_{2} \mathrm{~S}\right.$ ), $2.75-2.60(\mathrm{~m}, 1 \mathrm{H}, \mathrm{CH} \mathrm{Cy}), 1.75-1.12\left(\mathrm{~m}, 10 \mathrm{H}, \mathrm{CH}_{2} \mathrm{Cy}\right) .{ }^{1} \mathrm{H}$ NMR $\left(\mathrm{CDCl}_{3}\right) \delta 7.42(\mathrm{br}, 5 \mathrm{H}, \mathrm{Ar}), 7.29(\mathrm{~s}, 1 \mathrm{H}, \mathrm{CH}), 6.94(\mathrm{~s}, 1 \mathrm{H}, \mathrm{CH}), 5.39(\mathrm{~s}$, $2 \mathrm{H}, \mathrm{CH}_{2} \mathrm{Ph}$ ), 4.43 (t, J =7.2 Hz, $2 \mathrm{H}, \mathrm{NCH}_{2}$ ), 3.16 (br, $2 \mathrm{H}, \mathrm{CH}_{2} \mathrm{~S}$ ), $2.75-$ 2.60 (br, $1 \mathrm{H}, \mathrm{CH} \mathrm{Cy}), 1.80-1.20\left(\mathrm{~m}, 10 \mathrm{H}, \mathrm{CH}_{2} \mathrm{Cy}\right) .{ }^{13} \mathrm{C} \mathrm{NMR}\left(\mathrm{CD}_{3} \mathrm{CN}\right) \delta$ $137.9(\mathrm{Ar}), 134.9\left(\mathrm{C}_{\mathrm{NCN}}\right), 130.0(\mathrm{Ar}), 129.9(2 \mathrm{Ar}), 126.1(\mathrm{CH}), 125.0(\mathrm{CH})$, $55.2\left(\mathrm{CH}_{2} \mathrm{Ph}\right), 52.2\left(\mathrm{NCH}_{2}\right), 44.0(\mathrm{CHS}), 34.7\left(\mathrm{CH}_{2} \mathrm{Cy}\right), 29.6\left(\mathrm{CH}_{2} \mathrm{~S}\right)$, $26.8\left(\mathrm{CH}_{2} \mathrm{Cy}\right), 26.3\left(\mathrm{CH}_{2} \mathrm{Cy}\right)$. ESI-MS $\left(\mathrm{CH}_{3} \mathrm{CN}\right) \mathrm{m} / \mathrm{z}$ (\%): 957.04 (100) $\left[\mathrm{AuBr}_{2}\left(\mathrm{Bn} / \mathrm{m}^{\mathrm{Cy}}\right)_{2}\right]^{+}$.

\section{Biological results}

Cytotoxicity tests have been carried out at the "Institut de Chimie des Substances Naturelles CNRS - UPR2301, Gif-Sur-Yvette, France". Samples were prepared by dissolution of the compounds in DMSO except for cisplatin (used as reference) that was dissolved in water at stock concentrations of $10 \mathrm{mM}$. MCF7 (breast cancer cells) cell line was maintained as monolayers in RPMI 1640 medium supplemented with $10 \%$ fetal calf serum, in the presence of penicilline, streptomycine and fungizone in $75 \mathrm{~cm}^{2}$ flask under $5 \% \mathrm{CO}_{2}$. Cells were plated in 96-well tissue culture plates in $200 \mu \mathrm{l}$ complete medium at a density of $1000-$ 2500 cells per well and treated $24 \mathrm{~h}$ later with $2 \mu \mathrm{l}$ of compounds using a Biomek 3000 automation workstation (Beckman-Coulter). Controls received the same volume of the appropriate vehicle (DMSO or water, $1 \%$ final volume). After $72 \mathrm{~h}$ exposure, MTS reagent (CellTiter $96{ }^{8}$ Aqueous One, Promega) was added and incubated for $3 \mathrm{~h}$ at $37^{\circ} \mathrm{C}$ : the absorbance was monitored at $90 \mathrm{~nm}$ and results expressed as the inhibition of cell proliferation calculated as the ratio [(1-(OD490 reated/OD490 control)) $\times 100$ ] in triplicate experiments after subtraction of the blank without cells. Positive controls (cells incubated with a reference drug at its IC50 concentration) were routinely added to check the responsiveness of cells. For IC50 determination $[50 \%$ inhibition of cell proliferation], cells were incubated for $72 \mathrm{~h}$ following the same protocol with compound concentrations ranged $5 \mathrm{nM}$ to $100 \mu \mathrm{M}$ in separate duplicate experiments. At these concentrations, no interference with Pt or Au complexes was noticed at $490 \mathrm{~nm}$. Values are given as means \pm SD from at least three independent experiments performed in triplicate.

\section{Reactivity test of NHC gold(III) complexes and glutathione (GSH)}

Solutions of the NHC gold(III) complex (2 mM in DMSO- $d_{6}$, solution A) and GSH (4 mM in $\mathrm{D}_{2} \mathrm{O}$, solution $\mathrm{B}$ ) have been prepared. The ${ }^{1} \mathrm{H}-\mathrm{NMR}$ spectrum of GSH in DMSO- $d_{6} / \mathrm{D}_{2} \mathrm{O}(1: 1)$ and of the NHC-gold(III) complex in DMSO- $d_{6}$ have been recorded. Then, $0.5 \mathrm{~mL}$ of solution A + $0.5 \mathrm{~mL}$ of solution $B$ have been mixed and the ${ }^{1} \mathrm{H}$ NMR spectrum has been recorded immediately after the mixing.

\section{DFT calculations}

Density Functional Theory (DFT) calculations were carried out with the Amsterdam Density Functional (ADF) software, ${ }^{[49-52]}$ using the BLYP[53] functional corrected with the dispersion contribution term by Grimme et al. ${ }^{[54]}$ and employing the zeroth-order regular approximation (ZORA) ${ }^{[55]}$ to take into account relativistic effects, which are mandatory in the presence of heavy nuclei. ${ }^{[56]}$ The TZ2P basis set was used for all the elements. It is a large uncontracted set of Slater-type orbitals (STOs), is of triple- $\zeta$ quality and is augmented with two sets of polarization functions on each atom. In addition, core electrons were described with the frozen-core approximation: up to $1 \mathrm{~s}$ for $\mathrm{C}, \mathrm{N}, \mathrm{O}$ and $\mathrm{S}$, and up to $4 \mathrm{~d}$ in the case of $\mathrm{Au}$. For the numerical integration, the Becke grid was used. ${ }^{[57,58]}$ This level of theory, denoted ZORA-BLYP-D3(BJ)/TZ2P has already been employed with success in studies of the structural and electronic properties of $\mathrm{Au}(\mathrm{I})$ and $\mathrm{Au}(\mathrm{III}) \mathrm{NHC}$ complexes. ${ }^{[59]}$ Frequency calculations were carried out to assess the nature of the stationary points. Solvent effects were taken into account with the Conductor-like Screening Model (COSMO), ${ }^{[60,61]}$ which is implemented in the ADF program. For acetonitrile and chloroform, we used a solvent-excluding surface with an effective radius of $2.76 \AA$ and $3.17 \AA$, and a relative dielectric constant of 37.5 and 4.8 , respectively. The empirical parameter in the scaling function in the COSMO equation was set to 0.0 . The radii of the atoms were taken to be MM3 radii, ${ }^{[62]}$ divided by 1.2 , giving $1.350 \AA$ for $\mathrm{H}, 1.700 \AA$ for $\mathrm{C}, 1.608$ for $\mathrm{N}, 1.517$ for $\mathrm{O}, 1.792$ for $\mathrm{S}$ and $2.025 \AA$ for $\mathrm{Au} .{ }^{[63]}$ 


\section{Acknowledgements}

CARIPARO Foundation (Excellence Project 2018 «SELECT») and Università degli Studi di Padova (P-DiSC 2018, project $M A D^{3} S$ ) are acknowledged for partial financial support to this research. M.B. thanks the DAAD (Short-Term Grants, 2018 (57378443)) for a scholarship. R.D.M. acknowledges the Erasmus+ traineeship program for a fellowship.

Keywords: Gold complexes • N-heterocyclic carbene ligands • cytotoxic activity $\bullet$ thioether groups $\bullet$ oxidative addition

[1] S. Diez-Gonzalez, N-Heterocyclic Carbenes: From Laboratory Curiosities to Efficient Synthetic Tools, $2^{\text {nd }}$ Edition, 2017, Cambridge: RSC Catalysis Series, RSC.

[2] S. P. Nolan, N-Heterocyclic Carbenes, Effective Tools for Organometallic Synthesis, Wiley-VCH, Weinheim, 2014.

[3] H. V. Huynh, The organometallic chemistry of $\mathrm{N}$-heterocyclic carbenes, 2017, Hoboken, NJ: John Wiley \& Sons, Inc.

[4] L. Benhamou, E. Chardon, G. Lavigne, S. Bellemin-Laponnaz, V. César, Chem. Rev. 2011, 111, 2705-2733.

[5] H. M. Lee, C.-C. Lee, P.-Y. Cheng, Curr. Org. Chem. 2007, 11, 1491 1524.

[6] S. Hameury, P. de Frémont, P. Braunstein, Chem. Soc. Rev. 2017, 46, 632-733.

[7] S. T. Liddle, I. S. Edworthy, P. L. Arnold, Chem. Soc. Rev. 2007, 36, 1732-1744.

[8] R. E. Andrew, L. González-Sebastián, A. B. Chaplin, Dalton Trans. 2016, 45, 1299-1305.

[9] D. Pugh, A. A. Danopoulos, Coord. Chem. Rev. 2007, 251, 610-641.

[10] L. H. Gade, S. Bellemin-Laponnaz, Coord. Chem. Rev. 2007, 251, 718-725.

[11] E. Peris, Chem. Rev. 2018, 118, 9988-10031.

[12] M. Bierenstiel, E. D. Cross, Coord. Chem. Rev. 2011, 255, 574-590.

[13] D. Yuan, H. V. Huynh, Molecules 2012, 17, 2491-2517.

[14] C. Fliedel, P. Braunstein, J. Organomet. Chem. 2014, 751, 286-300.

[15] C. Fliedel, G. Schnee, P. Braunstein, Dalton Trans. 2009, 2474-2476.

[16] J. Wolf, A. Labande, J.-C. Daran, R. Poli, Eur. J. Inorg. Chem. 2007, 2007, 5069-5079.

[17] A. Labande, J.-C. Daran, N. J. Long, A. J. P. White, R. Poli, New J. Chem. 2011, 35, 2162-2168.

[18] F. Ulm, A. I. Poblador-Bahamonde, S. Choppin, S. Bellemin-Laponnaz, M. J. Chetcuti, T. Achard, V. Ritleng, Dalton Trans. 2018, 47, 1713417145.

[19] K. N. Sharma, N. Satrawala, R. K. Joshi, Eur. J. Inorg. Chem. 2018 2018, 1743-1751.

[20] C. Gandolfi, M. Heckenroth, A. Neels, G. Laurenczy, M. Albrecht, Organometallics 2009, 28, 5112-5121.[

[21] a) S. Ftouh, S. Bourgeade-Delmas, M. Belkadi, C. Deraeve, C. Hemmert, A. Valentin, H. Gornitzka, Organometallics DOI 10.1021/acs.organomet.1c00113. b) C. Zhang, S. Bourgeade Delmas, A. Fernández Álvarez, A. Valentin, C. Hemmert, H. Gornitzka, Eur. J. Med. Chem. 2018, 143, 1635-1643. c) C. Zhang, C. Hemmert, H. Gornitzka, O. Cuvillier, M. Zhang, R. Wai-Yin Sun, ChemMedChem 2018, 13, $1218-1229$.

[22] L. Ronconi, C. Marzano, P. Zanello, M. Corsini, G. Miolo, C. Maccà, A. Trevisan, D. Fregona, J. Med. Chem. 2006, 49, 1648-1657.

[23] M. Sooriyaarachchi, G. N. George, I. J. Pickering, A. Narendran, J. Gailer, Metallomics 2016, 8, 1170-1176.

[24] W. Chen, J. Egly, A. I. Poblador-Bahamonde, A. Maisse-Francois, S. Bellemin-Laponnaz, T. Achard, Dalton Trans. 2020, 49, 3243-3252.

[25] J. Egly, M. Bouché, W. Chen, A. Maisse-François, T. Achard, S. Bellemin-Laponnaz, Eur. J. Inorg. Chem. 2018, 2018, 159-166.

[26] H. M. J. Wang, I. J. B. Lin, Organometallics 1998, 17, 972-975.

[27] T. Scattolin, S. P. Nolan, Trends Chem. 2020, 2, 721-736.
[28] S. J. Roseblade, A. Ros, D. Monge, M. Alcarazo, E. Álvarez, J. M. Lassaletta, R. Fernández, Organometallics 2007, 26, 2570-2578.

[29] M. Iglesias, D. J. Beetstra, J. C. Knight, L.-L. Ooi, A. Stasch, S. Coles, L. Male, M. B. Hursthouse, K. J. Cavell, A. Dervisi, I. A. Fallis, Organometallics 2008, 27, 3279-3289.

[30] M. Monticelli, S. Bellemin-Laponnaz, C. Tubaro, M. Rancan, Eur. J. Inorg. Chem. 2017, 2017, 2488-2495.

[31] A. Collado, J. Bohnenberger, M.-J. Oliva-Madrid, P. Nun, D. B. Cordes, A. M. Z. Slawin, S. P. Nolan, Eur. J. Inorg. Chem. 2016, 2016, 41114122.

[32] N. V. Tzouras, F. Nahra, L. Falivene, L. Cavallo, M. Saab, K. V. Hecke, A. Collado, C. J. Collett, A. D. Smith, C. S. J. Cazin, S. P. Nolan, Chem. - Eur. J. 2020, 26, 4515-4519.

[33] P. de Frémont, R. Singh, E. D. Stevens, J. L. Petersen, S. P. Nolan, Organometallics 2007, 26, 1376-1385.

[34] A. Collado, A. Gómez-Suárez, A. R. Martin, A. M. Z. Slawin, S. P. Nolan, Chem. Commun. 2013, 49, 5541.

[35] M. Baron, C. Tubaro, M. Basato, A. A. Isse, A. Gennaro, L. Cavallo, C. Graiff, A. Dolmella, L. Falivene, L. Caporaso, Chem. - Eur. J. 2016, 22, 10211-10224.

[36] M. Baron, C. Tubaro, M. Basato, M. M. Natile, C. Graiff, J. Organomet. Chem. 2013, 723, 108-114.

[37] M. Baron, C. Tubaro, M. Basato, A. Biffis, M. M. Natile, C. Graiff, Organometallics 2011, 30, 4607-4615.

[38] J. C. Bernhammer, H. V. Huynh, Organometallics 2014, 33, 1266-1275.

[39] C. Hirtenlehner, C. Krims, J. Hölbling, M. List, M. Zabel, M. Fleck, R. J. F. Berger, W. Schoefberger, U. Monkowius, Dalton Trans. 2011, 40, 9899-9910.

[40] This process was investigated on the potential energy surface for a simplified model complex having a hydrogen as nitrogen-imidazole substituent and a methyl group as sulphur substituent. Starting from the chelated complex (with the methyl pointing upward), we have identified several minima on the PES lying at $+31.44 \mathrm{kcal} \mathrm{mol}^{-1}$ (a structure in which the Au-S bond is broken), at $+34.88 \mathrm{kcal} \mathrm{mol}^{-1}$ (a structure in which the methyl substituent of sulphur as well as the bromine nuclei have rotated by approximately 90 degrees) and at $+33.92 \mathrm{kcal} \mathrm{mol}^{-1}$ (a structure in which the methyl has rotated by approximately 90 degrees and is pointing downward).

[41] The same pathway was investigated also for the simplified model complex. Also in this case, the slightly stabilised reactant complex forms and is converted into the neutral tribromo complex through a low energy barrier (less than $1 \mathrm{kcal} \mathrm{mol}^{-1}$ ) (Figure S31).

[42] M. Kriechbaum, J. Hölbling, H.-G. Stammler, M. List, R. J. F. Berger, U. Monkowius, Organometallics 2013, 32, 2876-2884.

[43] C. Topf, C. Hirtenlehner, M. Zabel, M. List, M. Fleck, U. Monkowius Organometallics 2011, 30, 2755-2764.

[44] F. Schmitt, K. Donnelly, J. K. Muenzner, T. Rehm, V. Novohradsky, V. Brabec, J. Kasparkova, M. Albrecht, R. Schobert, T. Mueller, J. Inorg. Biochem. 2016, 163, 221-228.

[45] a) C. Schmidt, B. Karge, R. Misgeld, A. Prokop, R. Franke, M. Brönstrup, I. Ott, Chem. - Eur. J. 2017, 23, 1869-1880. b) F. Hackenberg, H. Müller-Bunz, R. Smith, W. Streciwilk, X. Zhu, M. Tacke, Organometallics 2013, 32, 5551-5560. c) F. Hackenberg, M. Tacke, Dalton Trans. 2014, 43, 8144-8153.

[46] M. Baron, S. Bellemin-Laponnaz, C. Tubaro, M. Basato, S. Bogialli, A. Dolmella, J. Inorg. Biochem. 2014, 141, 94-102.

[47] G. Boscutti, L. Marchiò, L. Ronconi, D. Fregona, Chem. - Eur. J. 2013, 19, 13428-13436.

[48] A. Nandy, T. Samanta, S. Mallick, P. Mitra, S. K. Seth, K. D. Saha, S. S. Al-Deyab, J. Dinda, New J. Chem. 2016, 40, 6289-6298.

[49] E. J. Baerends, D. E. Ellis, P. Ros, Chem. Phys. 1973, 2, 41-51.

[50] G. te Velde, F. M. Bickelhaupt, E. J. Baerends, C. Fonseca Guerra, S. J. A. van Gisbergen, J. G. Snijders, T. Ziegler, J. Comput. Chem. 2001, 22, 931-967.

[51] E. J. Baerends, et al., Computer code ADF2018, SCM, Theoretical Chemistry, Vrije Universiteit, Amsterdam, The Netherlands, 2018.

[52] A. D. Becke, Phys. Rev. A 1988, 38, 3098-3100.

[53] C. Lee, W. Yang, R. G. Parr, Phys. Rev. B 1988, 37, 785-789. 
[54] S. Grimme, S. Ehrlich, L. Goerigk, J. Comput. Chem. 2011, 32, 14561465.

[55] E. van Lenthe, E. J. Baerends, J. G. Snijders, J. Chem. Phys. 1994, 101, 9783-9792.

[56] a) F. Zaccaria, L. P. Wolters, C. Fonseca Guerra, L. Orian, J. Comput. Chem. 2016, 37, 1672-1680. b) M. Dalla Tiezza, F. M. Bickelhaupt, L. Orian, ChemistryOpen 2019, 8, 143-154. c) M. Dalla Tiezza, F. M. Bickelhaupt, L. Orian, ChemPhysChem 2018, 19, 1766-1773. d) S Masood Ahmad, M. Dalla Tiezza, L. Orian, Catalysts 2019, 9, 679. e) L. Orian, F. M. Bickelhaupt, Synlett 2021, 32, 561 - 572. f) A. Madabeni, P. A. Nogara, M. Bortoli, J. B. T. Rocha, L. Orian, Inorg. Chem. 2021 60, 4646-4656. g) L. Orian, W.-J. van Zeist, F. M. Bickelhaupt, Organometallics 2008, 27, 4028-4030.

[57] A. D. Becke, J. Chem. Phys. 1988, 88, 2547-2553.

[58] M. Franchini, P. H. T. Philipsen, L. Visscher, J. Comput. Chem. 2013 34, 1819-1827.

[59] a) M. Baron, A. Dall'Anese, C. Tubaro, L. Orian, V. Di Marco, S. Bogialli, C. Graiff, M. Basato, Dalton Trans. 2018, 47, 935-945. b) M. Baron, C Tubaro, M. L. C. Cairoli, L. Orian, S. Bogialli, M. Basato, M. M. Natile, C. Graiff, Organometallics 2017, 36, 2285-2292. c) V. Stoppa, T. Scattolin, M. Bevilacqua, M. Baron, C. Graiff, L. Orian, A. Biffis, I. Menegazzo, M Roverso, S. Bogialli, F. Visentin, C. Tubaro, New J. Chem. 2021, 45, 961-971.

[60] A. Klamt, G. Schüürmann, J. Chem. Soc. Perkin Trans. 2 1993, 799_ 805

[61] A. Klamt, J. Phys. Chem. 1995, 99, 2224-2235.

[62] C. C. Pye, T. Ziegler, Theor. Chem. Acc. 1999, 101, 396-408.

[63] N. L. Allinger, X. Zhou, J. Bergsma, J. Mol. Struct. THEOCHEM 1994 $312,69-83$ 


\section{Entry for the Table of Contents}

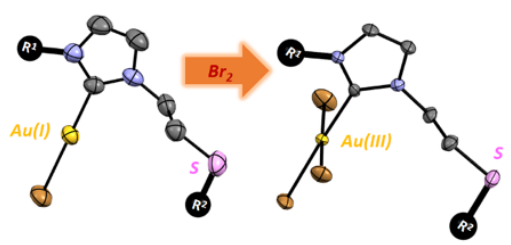

Gold $(\mathrm{I}, \mathrm{III})$ complexes with N-heterocyclic carbene ligands having a thioether side-arm have been synthesised and fully characterised; their antiproliferative properties have been also evaluated. 